\title{
Contratos, licitaciones
}

y servicios públicos a

la luz de los tratados

internacionales de

derechos humanos

incorporados en el

derecho brasilero ${ }^{1}$

Felipe Klein Gussoli ${ }^{2}$

\section{RESUMEN}

El artículo busca identificar cómo los tratados internacionales en derechos humanos determinan directa o indirectamente el régimen jurídico de los contratos administrativos, las licitaciones y los servicios públicos, incluso cuando estos son delegados a particulares. La investigación parte de un análisis de las reglas convencionales y de cómo estas llegan a regular las relaciones entre

1 El presente artículo inédito fue traducido del portugués al español por el profesor William Iván Gallo Aponte, amigo, a quien agradezco enormemente por el trabajo dedicado.

2 Profesor de pregrado y posgrado en licitaciones y contratos administrativos de la Pontificia Universidad Católica del Paraná, Curitiba (PR), Brasil. Doctorando en Derecho por la Universidad Federal del Paraná, Curitiba (PR), Brasil. Integrante del Núcleo de Investigações Constitucionais da Universidade Federal do Paraná (NINC-UFPR). Abogado independiente. Correo-e: gussoli@hotmail.com. Enlace ORCID: https://orcid.org/00000002-2585-6548. Fecha de recepción: 26 de febrero de 2020. Fecha de modificación: 20 de abril de 2020. Fecha de aceptación: 2 de mayo de 2020. Para citar el artículo: Gussoli, FeLIPE KLEIN, "Contratos, licitaciones y servicios públicos a la luz de los tratados internacionales de derechos humanos incorporados en el derecho brasilero" Revista digital de Derecho Administrativo, Universidad Externado de Colombia, n. ${ }^{\circ} 24,2020$, pp. 43-77. DOI: https:// doi.org/10.18601/21452946.n24.03. 
la Administración y los particulares. El estudio de estas influencias verticales sobre el derecho administrativo interno es ejemplificado a partir de un examen del derecho brasilero de los contratos y licitaciones públicas, y en materia de servicios públicos. De esta manera, se identifican las principales alteraciones que las reglas contenidas en tratados internacionales en derechos humanos producen en el régimen de las concesiones de servicios públicos, una vez son incorporados en el derecho interno.

Palabras clave: convencionalidad, Sistema Interamericano de Derechos Humanos, derecho interno, contrataciones públicas, concesión de servicios públicos, licitaciones públicas.

\section{Contracts, Bids and Public Services in the Light of International Human Rights Treaties Incorporated into Brazilian Domestic Law}

\section{ABSTRACT}

This article seeks to identify how international treaties on human rights directly or indirectly impact the legal framework of procurements, bids, and public services. The research starts by examining how conventional rules regulate relationships between the Administration and individuals. The study of these vertical influences on national administrative law is exemplified by means of an analysis of the Brazilian law of public procurements, bids and publics services. This academic exercise allowed to identify the main changes brought by international human rights conventions on the regime of public service concessions, once they are incorporated into domestic law.

Keywords: Conventionality; Inter-American Human Rights System, Domestic Law ${ }_{i}$ Public Procurement ${ }_{i}$ Concession of Public Services, Public Bids.

\section{INTRODUCCIÓN}

No es de extrañarse que en el estudio del sistema de contrataciones públicas se presente una omisión con relación a la influencia que pueden tener los tratados internacionales de derechos humanos en las mismas; eso ocurre incluso en el campo de los estudios relacionados con los servicios públicos, delegados o no a los particulares. Sin la pretensión de agotar el tema, el trabajo busca contribuir a suplir esta laguna, demostrando que, en el paradigma de la convencionalidad, los tratados internacionales de derechos incorporados pueden tener un impacto significativo en la elaboración, interpretación y aplicación de normas que reglamentan las licitaciones, los contratos administrativos y los servicios públicos. 
A pesar de enfocarse en el régimen jurídico brasilero de contrataciones y servicios públicos, el artículo presenta también un análisis de la convencionalidad en todo el Sistema Interamericano de Derechos Humanos (SIDH) ${ }^{3}$, del cual Brasil, junto con todos los demás signatarios, hacen parte de la Convención Americana sobre Derechos Humanos (Pacto de San José de Costa Rica).

Los derechos humanos sirven a la interpretación y operatividad del derecho administrativo y sus instituciones. De esta manera, es necesario identificar en las relaciones jurídico-administrativas qué tan efectivo y transversal es el derecho internacional de los derechos humanos. Para esto, se abordará en qué medida la llamada convencionalidad influencia el régimen normativo en países que incorporan tratados internacionales de derechos humanos, con especial atención a los sistemas Universal e Interamericano de Derechos Humanos. Visto esto, será analizado de qué modo las convenciones internacionales influencian las licitaciones públicas, en especial, a partir de la Convención de las Naciones Unidas contra la Corrupción. Seguidamente, se pasará a la lectura convencional de las cláusulas exorbitantes en contratos administrativos y al análisis del régimen de prestación de servicios públicos, sean prestados directa o indirectamente por el Poder Público.

\section{LA CONVENCIONALIDAD COMO PARADIGMA DE LAS RELACIONES JURÍDICO-ADMINISTRATIVAS ENTRE EL PODER PÚBLICO Y LOS PARTICULARES}

Las convenciones internacionales de derechos nunca tuvieron tanta importancia para el estudio y la aplicación del derecho. De acuerdo con Jaime Orlando Santofimio Gamboa, la

convencionalidad domina [...] el pleno funcionamiento de los Poderes Públicos de todos los Estados, así como la actividad de todas sus autoridades, penetrando espacios o esferas debajo de criterios de preponderancia y vinculatoriedad, en escenarios de la más variada naturaleza, como los que se refieren a las decisiones que se deban tomar en aspectos relacionados con los derechos humanos, sociales, políticos, militares, económicos, etc. ${ }^{4}$.

3 El Sistema Interamericano tiene como principales órganos la Organización de los Estados Americanos (OEA), la Comisión Interamericana de Derechos Humanos y la Corte Interamericana de Derechos Humanos. Para una comprensión del Sistema a partir de la historia de la Comisión, véase Alfonso Santiago y Gardner LanGe, "Los primeros sesenta años de la Comisión Interamericana de Derechos Humanos", A\&C - Revista de Direito Administrativo \& Constitucional, Belo Horizonte, n. ${ }^{\circ} 77,2019$, pp. 11-57. DOI: 10.21056/aec.v19i77.1158. Jaime Orlando Santofimio Gamboa, El concepto de convencionalidad: vicisitudes para su construcción sustancial en el sistema interamericano de derechos bumanos. Ideas fuerza rectoras, tesis posdoctoral, Universidad Carlos III de Madrid, 2016, p. 30 
O sea, la convencionalidad irradia efectos a todo el ordenamiento jurídico. Los tratados internacionales de derechos humanos incorporados en determinado sistema jurídico son recepcionados como normas jurídicas válidas y vigentes, que necesitan ser operacionalizadas en conjunto con vehículos normativos de otras especies.

Diversas constituciones latinoamericanas reconocieron a partir del final de los años ochenta la fuerza normativa de los tratados de derechos humanos, lo que fue parte de una corriente de expansión de derechos fundamentales y fortalecimiento de las instituciones de garantía. Entre ellas, las constituciones de Chile, Perú, Venezuela, Ecuador, Bolivia y Colombia ${ }^{5}$. En Brasil, la Constitución de 1988 prevé varias normas respecto de los tratados internacionales de derechos humanos, a saber: artículos $4 . \mathrm{I}, 5 \S \S 1 .^{\circ}, 2 .^{\circ}$ y $3 .^{\circ}, 102 . I I I . b$ y 105.III. $\mathrm{a}^{6}$. El Supremo Tribunal Federal, al interpretar la Constitución, definió la jerarquía supralegal e infraconstitucional de los tratados de derechos humanos incorporados en Brasil, en el Recurso Extraordinario n. ${ }^{\circ} 466.343-S P$, decisión de 2008. Y aunque haya una discusión incesante sobre la jerarquía de los tratados, con una posible revisión de la interpretación hoy vigente, el hecho es que por lo menos la convencionalidad es reconocida como una realidad en el escenario jurídico brasilero. La aceptación de que los tratados internacionales de derechos humanos son instrumentos que ostentan fuerza normativa, al menos supralegal, ya permite inferir que se vive un paradigma en donde las convenciones de derechos humanos regulan la interpretación y el control de las demás especies normativas ${ }^{7}$.

Jesús M. CASAl HeRnánDEZ, "El constitucionalismo latinoamericano y la oleada de reformas constitucionales en la región andina", Rechtsgeschichte, vol. 16, 2010, pp. 219-220.

6 Constitución Federal de Brasil, artículo. 4: "La República Federativa de Brasil se rige en sus relaciones internacionales por los siguientes principios: [... ] II. prevalencia de los derechos humanos".

Artículo 5: "§ 1. ${ }^{\circ}$ Las normas definidoras de los derechos y garantías fundamentales tienen aplicación inmediata. $§ 2 .^{\circ}$ Los derechos y garantías expresos en esta Constitución no excluyen otros decorrentes del régimen y de los principios por ella adoptados, o de los tratados internacionales en que la República Federal de Brasil sea parte. $§ 3 .^{\circ}$ Los tratados y convenciones internacionales sobre derechos humanos que fuesen aprobados, en cada Cámara del Congreso Nacional, en dos momentos, por tres quintos de los votos de los respectivos miembros, serán equivalentes a las enmiendas constitucionales".

Artículo 102. "Compete al Supremo Tribunal federal, en primer lugar, la guarda de la Constitución, cabiéndole: [...] III. Juzgar, mediante recurso extraordinario, las causas decididas en única o última instancia cuando la decisión recurrida: b) declarar la inconstitucionalidad del tratado o ley federal".

Artículo 105. "Compete al Supremo Tribunal de Justicia ${ }_{i}[\ldots$. . III. Juzgar, en recurso especial, las causas decididas, en única o última instancia, por los Tribunales Regionales Federales o por los tribunales de los Estados, del Distrito Federal y Territorios, cuando la decisión recurrida: a) sea contraria al tratado o a la ley federal, o niegue su vigencia".

7 FeliPE KLEIN GusSOLI, "Dez parâmetros básicos de atuação da Administração Pública segundo os tratados internacionais de direitos humanos", Revista Digital de Direito Administrativo, 
Se defiende, entonces, la existencia de un paradigma de la convencionalidad orientador de la interpretación y la aplicación de normas jurídicas, inclusive, aquellas de derecho Administrativo, en licitaciones y contratos administrativos celebrados entre el Poder Público y los particulares, sean estos personas naturales o jurídicas ${ }^{8}$. En cuanto a estas últimas, se ha señalado por la Corte Interamericana de Derechos Humanos (Corte IDH) que no son titulares de derechos humanos, conforme lo decidió la en la Opinión Consultiva n. ${ }^{\circ} 22 / 16^{[9]}$. Sin embargo, la misma Corte IDH ya reconoció que el ejercicio de derechos humanos de individuos acontece en la mayoría de las veces por medio de personas jurídicas ${ }^{10}$. En el paradigma de la convencionalidad afirmado anteriormente, la licitación y el contrato administrativo firmados entre el Poder Público y las personas jurídicas prestadoras de servicios públicos tienen una notable importancia en el ejercicio de derechos básicos de todas las personas humanas. Es justamente a través de la licitación, del contrato administrativo y del servicio público que la población evidencia el desarrollo de una gran parte del actuar público.

\section{RÉGIMEN LICITATORIO Y CONVENCIONALIDAD: ESPECIAL ATENCIÓN A LA CONVENCIÓN DE LAS NACIONES UNIDAS CONTRA LA CORRUPCIÓN}

En Brasil, el deber de licitar está previsto en el artículo 37.XxI de la Constitución ${ }^{11}$. Odete Medauar define la licitación como el "proceso administrativo

Ribeirão Preto, vol. 6, 2019, p. 48. DOI: 10.11606/issn.2319-0558.v6i2p46-70.

8 Para un análisis más amplio acerca de los impactos de la convencionalidad en el derecho administrativo, cfr. FeliPe Klein GuSsoli, "Releitura do regime jurídico-administrativo e a teoria do melhor direito: impactos da convencionalidade no Sistema Interamericano de Direitos Humanos", Opinião Jurídica, Fortaleza, 2019. DOI: 10.12662/2447-6641oj. v0i0.p\%25p.0. Disponible en: https://periodicos.unichristus.edu.br/opiniaojuridica/article/ view/2843.

9 Corte Interamericana de Derechos Humanos, Titularidad de derechos de las personas jurídicas en el Sistema Interamericano de Derechos Humanos (interpretación y alcance del artículo 1.2, en relación con los artículos 1.11, 8, 11.2, 13, 16, 21, 24, 25, 29, 30, 44, 46, e 62.3 de la Convención Americana sobre Derechos Humanos, así como el artículo 8.1 A e B del Protocolo de San Salvador). Opinión Consultiva n. ${ }^{\circ} 22 / 16$. Publicada el 26 de febrero de 2016.

10 Corte Interamericana de Derechos Humanos, Caso Granier y otros (Radio Caracas Televisión) vs. Venezuela. Sentencia del 22 de junio de 2015, §§ 19-22.

11 Constitución Federal de Brasil, artículo 37: "[... X xxı. salvo los casos especificados en la legislación, las obras, servicios, compras y enajenaciones serán contratados mediante proceso de licitación pública que asegure igualdad de condiciones a todos los concurrentes, con cláusulas que establezcan obligaciones de pago, mantenimiento las condiciones efectivas de la propuesta, en los términos de la ley, lo cual solamente permitirá las exigencias de cualificación técnica y económica indispensables para la garantía del cumplimiento de las obligaciones". 
en que la sucesión de fases y actos lleva a la selección de quien va a celebrar el contrato con la Administración. Por lo tanto, al seleccionar quien va a contratar con la Administración, por ofrecer la propuesta más ventajosa al interés público $^{\prime 12}$. La licitación es un instrumento o herramienta regulado actualmente en conjunto con el contrato administrativo por la Ley Federal n. ${ }^{\circ} 8.666 / 93$, sin perjuicio de otras leyes, como, por ejemplo, la Ley n. ${ }^{\circ} 13.303 / 2016$ (Estatuto Jurídico de las Empresas Estatales Federales) ${ }^{13}$, la Ley n. ${ }^{\circ}$ 12.462/2011 (Régimen Diferenciado de Contrataciones) y la Ley n. ${ }^{\circ} 10.520 / 2002$ (Pregão $0^{14}$. El régimen licitatorio brasilero es bastante complejo y está en camino de ser modificado por la nueva Ley General de Licitaciones. El proyecto de Ley del Senado n. ${ }^{\circ}$ 559/2013 (Proyecto de Ley n. ${ }^{\circ}$ 6814/2017 en la Cámara Federal) busca la derogación y sustitución de la Ley n. ${ }^{\circ}$ 8.666/1993, del Régimen Diferenciado de Contrataciones y de la propia Ley del Pregão. Busca, en suma, unificar las legislaciones. No obstante, la lectura actual del proyecto, que muy probablemente será aprobado en breve, muestra que el sistema permanecería complejo, con reglas detalladas y extensas sobre los procesos de selección en la contratación pública. Así como ya ocurre hoy en la vigencia de la Ley n. ${ }^{\circ}$ $8.666 / 1993$, todo indica que no serán disipadas las dudas en torno a quiénes son los servidores responsables de la conducción de las licitaciones, lo que causa, en lo mínimo, inseguridad jurídica en los particulares participantes de los procesos licitatorios y los futuros contratistas.

El sistema brasilero de selección y contratación pública, bajo el pretexto de regular minuciosamente la licitación, todavía da espacio para fraudes o tentativas de violación de reglas, en perjuicio de la finalidad última que sería la selección del mejor oferente. El gran número de órganos de control hasta el momento no parece ser el mecanismo adecuado para la corrección de las fallas inherentes al sistema. Más allá de eso, no es raro que se confunda la mejor propuesta con la selección del menor precio, lo que, ignorando las reglas del mercado, termina por adicionar a los contratos valores adicionales a la media (o termina por seleccionar productos y servicios de mala calidad para la Administración y, por consiguiente, para la población que utiliza de los servicios y obras públicas, y es destinataria de actividad administrativa).

En el tema de las licitaciones y contrataciones públicas, la Convención de las Naciones Unidas contra la Corrupción, ratificada en Brasil por el Decreto

12 Odete Medauar, "Direito administrativo moderno". Revista dos Tribunais, São Paulo, 2014 p. 203.

13 Para una introducción en las licitaciones en las empresas estatales a partir de la Ley n. ${ }^{\circ}$ 13.303/2016, cfr. Fabianne Mazzaropp y Felipe Klein Gussoli, "Licitação e nova lei das estatais federais: caminhos para o desenvolvimento e sustentabilidade na Administração Pública Indireta", en Luiza de Araújo Furiatti, Maria Augusta Souza y Janaína Bettes (orgs.), O Direito entre o desenvolvimento e a sustentabilidade, Curitiba: CRV, 2017, pp. 91-106.

14 Análogo a Ley de la Subasta Inversa. 
n. ${ }^{\circ} 5.687 / 2006^{[15]}$, dispone en el artículo 9.1 el deber de los Estados de adoptar sistemas de contratación pública transparentes y eficaces:

Cada Estado Parte, de conformidad con los principios fundamentales de su ordenamiento jurídico, adoptará las medidas necesarias para establecer sistemas apropiados de contratación pública, basados en la transparencia, en la competencia y en criterios objetivos de adopción de decisiones, que sean eficaces, entre otras cosas, para prevenir la corrupción ${ }^{16}$.

A partir del texto, se observa que el combate contra las prácticas de corrupción es una preocupación latente de los países. En Colombia, por ejemplo, el riesgo de la corrupción en los contratos públicos es una preocupación demostrada en estudios recientes ${ }^{17}$, con serias implicaciones para los derechos humanos. Por eso, la regulación del sistema de selección contractual de la Administración tiene un papel fundamental según la Convención de las Naciones Unidas contra la Corrupción.

El primer impacto relevante del tratado mencionado, aunado a la interpretación propersona, es que desafía toda disposición legal o reglamentaria brasilera que contribuya a contrataciones ineficaces o que propicie prácticas corruptas, esto es, que represente obstáculos para la buena contratación pública. Es, por ejemplo, el caso de aquella contratación relacionada con la habilitación previa a la que se sujetan los participantes (artículo 27 de la Ley n. ${ }^{\circ}$ 8.666/93);

15 Los drásticos efectos del desvío de recursos y acciones públicas para fines privados en la vida concreta de los seres humanos no son una exclusividad brasilera, lo que llevó a la Organización de los Estados Americanos, el 29 de marzo de 1996, a elaborar la Convención Interamericana contra la Corrupción (Decreto 4.410/2002), y la Organización de las Naciones Unidas a promulgar, el 14 de diciembre de 2005, la citada la Convención de las Naciones Unidas contra la Corrupción Decreto n. ${ }^{\circ}$ 5687/2006). Ambas, sin duda, son tratados de derechos humanos, porque resguardan todavía que indirectamente derechos fundamentales básicos de los ciudadanos y no simplemente relaciones entre Estados. Sobre la primera convención internacional destinada a combatir la corrupción. Cfr. LaRISSA Ramina, "A Convenção Interamericana contra a corrupção: uma breve análise". Revista Direitos Fundamentais \& Democracia, vol. 6, n. ${ }^{\circ}$ 6, 2009; y LARISSA RAMINA, "Tratamento jurídico internacional da corrupção: a Convenção Interamericana contra a Corrupção da OEA e a Convenção sobre o Combate da Corrupção de Funcionários Públicos Estrangeiros em Transações Comerciais da OCDE", Revista da Faculdade de Direito UFPR, vol. 39, 2003.

16 La relevancia de la transparencia en el ámbito de la contratación pública como medida para evitar la corrupción es resaltada por CAROLINE MülLER BiTENCOURT y JANRIÊ RodRigueS RECK, "Controle da transparência na contratação pública no Brasil - o acesso à informação como forma de viabilizar o controle social da Administração Pública", en Jaime RodríguezArana Muñoz, Rogério Gesta Leal, Caroline Müller Bitencourt y Carlos Aymerich Cano (coords.), La respuesta jurídica a la corrupción en la contratación pública en Brasil y España, Navarra: Aranzadi, 2016, pp. 77-101.

17 William Iván Gallo ApOnTE, “Una aproximación al 'riesgo de corrupción' en los contratos públicos", A\&C - Revista de Direito Administrativo \& Constitucional, n. ${ }^{\circ} 75,2019$, pp. 39-64. DOI: 10.21056/aec.v20i75.1081. 
reglas de este tipo serían inconvencionales por afrontar el deber de eficacia del artículo 91 de la Convención de las Naciones Unidas contra la Corrupción.

La alegación de ineficacia absoluta de un procedimiento determinado en la ley debe ser motivada y demostrada detalladamente por quien desea declararla, lo que solo será posible cuando no restrinja la esfera jurídico-patrimonial de cualquiera de los participantes competidores. Por eso, para declarar reglas legales o reglamentarlas ineficaces, hay un requisito temporal indispensable: sea cual sea, se admite la derogatoria de una regla procesal con base en el argumento de la ineficacia de su aplicación, cuando ella fuese justificada en el proceso de la fase interna de la licitación y conste expresamente en el edicto publicado por el Poder Público.

Otro impacto directo en el derecho administrativo deviene de la Convención de la ONu contra la Corrupción, un tratado de derechos humanos, y se deriva de la previsión en el artículo 9.1.b de la obligatoriedad de "mecanismos eficaces de control interno, incluyendo un sistema eficaz de apelación, para garantizar recursos y soluciones legales en el caso de que no se respeten las reglas o los procedimientos establecidos". O sea, no basta la previsión formal de recursos administrativos cuya decisión se sabe que se repetirá ante el mismo órgano decisorio, porque el tratado internacional es claro en el sentido de que el sistema recursal en los procesos licitatorios debe ser eficaz, so pena de inconvencionalidad. Ser eficaz presupone la capacidad para desarrollar la finalidad recursal, que es la reforma de la decisión cuando el primer acto practicado fue ilícito.

La regla determinante de un sistema de recursos en el proceso licitatorio eficaz presupone en lo mínimo: a) plazos razonables para la formulación de las razones objeto del recurso; b) acceso completo y facilidad a los documentos del proceso de licitación y a todos los otros documentos que sustentaron la decisión, como extensión de términos iniciales de plazo para la fecha de efectivización de acceso a los expedientes ${ }_{i}$ c) ampliación de la legitimidad del recurso para todo sujeto que demuestre interés en el resultado de la licitación; y d) motivación detallada de las razones de procedencia o no del recurso, pues a todos los interesados se les debe permitir el acceso a la justificación de la decisión, material con el cual podrán manifestarse en instancias adecuadas si así lo desean.

El sistema de recursos administrativos deseado por la normatividad internacional se presume eficaz cuando es serio, y no meramente una formalidad expuesta en la legislación para dar un falso cumplimiento a las determinaciones convencionales. Si se da el caso de que el recurso administrativo en la licitación no se muestre el medio eficaz de combate contra las decisiones ilícitas o prácticas fraudulentas, sea por repetir sistemáticamente la posición administrativa ya reiteradamente superada por los tribunales, o sea por incumplir alguno de los criterios de eficacia, la práctica será contraria a la Convención y deberá ser anulada de oficio por la Administración en el ejercicio del control 
de convencionalidad, o por el Poder Judicial cuando se recurra al mismo. Vale la pena recordar que, en Brasil, el acceso al Poder Judicial no carece de agotamiento de la vía administrativa, siguiendo la norma del artículo 5.xxxv de la Constitución: "La ley no excluirá de la apreciación del Poder Judicial lesión o amenaza al derecho".

Se subraya que un sistema de recursos adecuado en el proceso administrativo de licitación es imposible sin que la regla del artículo 9.1.y de la Convención de la ONU contra la Corrupción sea cumplida. La norma obliga a "reglamentar las cuestiones relativas al personal encargado de la contratación pública"18, lo que implica "procedimientos de preselección y requisitos de capacitación". No se admite más que servidores públicos sin el debido conocimiento de las reglas de licitación actúen en procesos licitatorios, factor que contribuye no solo a deslegitimar la acción estatal, sino que igualmente torna ineficaz el proceso de selección.

Sin agotar el tema, es posible todavía identificar otros tratados internacionales que, cotejados con dispositivos de reglas brasileras sobre licitaciones, generan inconvencionalidades. Para citar dos ejemplos, siguiendo la interpretación del artículo 13 de la Convención Americana ${ }^{19}$, se tiene que al menos dos dispositivos de la Ley n. ${ }^{\circ} 13.303 / 2016$ y la Ley n. ${ }^{\circ}$ 12462/2011 afrontan la regla convencional de acceso amplio a la información ${ }^{20}$. Sus artículos 34 y

18 En Brasil, la Ley n. ${ }^{\circ}$ 12847/2013 reglamentó la punición a servidores públicos que practiquen actos ilícitos en procesos licitatorios. Artículo 5: "Constituem atos lesivos à administração pública, nacional ou estrangeira, para os fins desta Lei, todos aqueles praticados pelas pessoas jurídicas mencionadas no parágrafo único do art. $1^{\circ}$, que atentem contra o patrimônio público nacional ou estrangeiro, contra princípios da administração pública ou contra os compromissos internacionais assumidos pelo Brasil, assim definidos: IV - no tocante a licitações e contratos: a) frustrar ou fraudar, mediante ajuste, combinação ou qualquer outro expediente, o caráter competitivo de procedimento licitatório público; b) impedir, perturbar ou fraudar a realização de qualquer ato de procedimento licitatório público; c) afastar ou procurar afastar licitante, por meio de fraude ou oferecimento de vantagem de qualquer tipo; d) fraudar licitação pública ou contrato dela decorrente,$e$ ) criar, de modo fraudulento ou irregular, pessoa jurídica para participar de licitação pública ou celebrar contrato administrativo; $f$ ) obter vantagem ou benefício indevido, de modo fraudulento, de modificações ou prorrogações de contratos celebrados com a administração pública, sem autorização em lei, no ato convocatório da licitação pública ou nos respectivos instrumentos contratuais; ou g) manipular ou fraudar o equilíbrio econômico-financeiro dos contratos celebrados com a administração pública". Para un análisis de la ley, editada para atender compromisos internacionales asumidos en tratados internaciones por Brasil, bien como mecanismos que ella trae para combatir la corrupción, cfr. Emerson Gabardo y Gabriel Morettini Castella, "A nova lei anticorrupção e a importância do compliance para as empresas que se relacionam com a Administração Pública", A\&C - Revista de Direito Administrativo \& Constitucional, n. ${ }^{\circ} 60,2015$, pp. 129-147.

19 "Esse direito abrange o de difundir e expandir tais informações a quem quer que seja. Em contrapartida, importa também no direito que todas pessoas têm de receber informações de qualquer natureza ou de procurar por elas". Luiz Flávio Gomes y Valerio de Oliveira Mazzuoli, Comentários à Convenção Americana sobre Direitos Humanos: Pacto de San José da Costa Rica, 4. ${ }^{a}$ ed. São Paulo: Revista dos Tribunais, 2013, pp. 177-178.

20 El derecho de información gana importancia también en Colombia. En materia de regulación, el asunto fue explorado por Aníbal Zárate y Camilo Perdomo Villamil, "El deber de 
$6^{[21]}$, respectivamente, determinan que para el precio estimado del contrato a ser licitado habrá reserva hasta el final del proceso de selección. Se presume que el secreto de los precios máximos del contrato provocaría ofertas más bajas por parte de los oferentes.

No obstante, reglas que establecen la reserva de los valores que la Administración pretende practicar en sus contrataciones son inconvencionales por establecer una condición de secreto cuya finalidad no es identificada en la práctica. Contrario a lo que los defensores del secreto podrían argumentar, omitir los precios definidos después de la prospección no garantiza que los oferentes no presenten propuestas por debajo del precio de mercado (al menos no es lo que se espera que hagan), precio que, inclusive, debe ser aquel encontrado por la Administración en la fase interna de la licitación. El secreto en esos casos contraría el derecho de acceso amplio a la información pública sin una justificación idónea y racional. De otro lado, abrir los precios al público garantiza conocimiento general de los valores que la Administración aplicó para la contratación en sus investigaciones de la fase interna y permite impugnaciones sobre la corrección de los valores alcanzados, asunto en el cual los oferentes están, la mayoría de las veces, en mejores condiciones de conocer que el Poder Público, pues tienen mayor conocimiento de su mercado.

Se nota, por ende, que hay intersecciones entre la legislación sobre licitaciones y las convenciones de derechos humanos, y que es este un campo fértil de estudios. El buen funcionamiento de la Administración, la manutención de sus bienes y un adecuado sistema de delegaciones de actividades depende de reglas licitatorias eficaces que traduzcan la suscripción de contratos administrativos con potencial de atención que satisfaga los intereses públicos, finalidad de la cual todos los ciudadanos se han de beneficiar.

información como presupuesto procedimental para el ejercicio de la potestad reglamentaria en Colombia", A\&C - Revista de Direito Administrativo \& Constitucional, n. ${ }^{\circ}$ 76, 2019 pp. 41-82. DOI: $10.21056 /$ aec. v19i76.1076.

21 Ley n. ${ }^{\circ} 12.462 / 2011$, artículo 6: "Observado o disposto no $\S 3^{\circ}$, o orçamento previamente estimado para a contratação será tornado público apenas e imediatamente após o encerramento da licitação, sem prejuízo da divulgação do detalbamento dos quantitativos e das demais informações necessárias para a elaboração das propostas". Ley n. ${ }^{\circ}$ 13.303/2016, Artículo 34: "O valor estimado do contrato a ser celebrado pela empresa pública ou pela sociedade de economia mista será sigiloso, facultando-se à contratante, mediante justificação na fase de preparação prevista no inciso I do art. 51 desta Lei, conferir publicidade ao valor estimado do objeto da licitação, sem prejuizo da divulgação do detalhamento dos quantitativos e das demais informações necessárias para a elaboração das propostas". 


\section{RÉGIMEN DE CONTRATACIÓN PÚBLICA BRASILERO Y CONVENCIONALIDAD: REVISIÓN DE LA TEORÍA DE LAS CLÁUSULAS EXORBITANTES}

Al lado de las reflexiones sobre los impactos de los tratados internacionales de derechos humanos en las licitaciones, está el análisis de las transformaciones por las cuales pasa el régimen de los contratos administrativos delante del derecho administrativo y en relación con el derecho internacional de los derechos humanos.

Según José dos Santos Carvalho Filho, un contrato administrativo es "el ajuste firmado entre la Administración pública y un particular, regulado básicamente por el derecho público, y teniendo por objeto una actividad que, de alguna forma, traduce interés público ${ }^{\prime 22}$. Marçal Justen Filho sigue una orientación diversa y define el contrato administrativo en sentido amplio como un "acuerdo de voluntades destinadas a crear, modificar o extinguir derechos y obligaciones, tal como facultado legislativamente y en que por lo menos una de las partes actúa en el ejercicio de la función administrativa"23. Encontramos que esta última definición es más apropiada, pues permite aplicar el régimen contractual administrativo también a los delegatarios de la Administración en las concesiones, permisos y autorizaciones. Sin embargo, aunque esta definición es adecuada, es preciso recordar que, como hace el propio autor citado, en Brasil hay innumerables tipos de contratos administrativos, de modo que una definición amplia nunca conseguiría identificar los detalles de cada uno.

La variedad y cantidad de tipos contractuales no impide que comúnmente parte de la doctrina y la jurisprudencia ${ }^{24}$ asocien para cualquiera de ellos una característica fundamental, siendo esta la presencia de cláusulas exorbitantes. Dichas cláusulas cualifican las prerrogativas del Poder Público o de quien haga las veces en el contrato administrativo, lo que según Celso Antonio Bandeira de Mello se traduce en los poderes:

22 José dos Santos Carvalho Filho, Manual de Direito Administrativo, 24. ${ }^{a}$ ed., Río de Janeiro: Lumen Juris, 2011, p. 181.

23 Marçal Justen Filho, Curso de Direito Administrativo. 11. a ed., São Paulo: Revista dos Tribunais, 2015, p. 452.

24 El Tribunal Superior de Justicia caracteriza en cualquier contrato de la Administración prerrogativas correspondientes a las cláusulas exorbitantes. Cita a modo de ejemplo la siguiente decisión: "No presente caso, o objeto do contrato não consiste em prestação de serviço público, tamponco traduz diretamente uma utilidade pública fruivel pelos administrados. O traço de verticalidade e a posição do ente público como detentor do jus imperium se fazem menos presentes nesse tipo de contrato de Direito Privado da Administração, embora lhe seja natural a incidência de algumas normas derrogadoras do direito comum, que se manifestam pelas denominadas cláusulas exorbitantes". Brasil, Superior Tri-

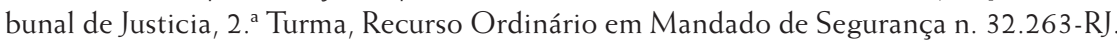
Julgamento el 20 de noviembre de 2012. Publicado el 18 de diciembre de 2012. 
a) de modificarlo, unilateralmente, para una mejor adecuación a las finalidades del interés público, pero con variaciones de cantidad y precios ceñidos a los dispuestos en la ley ${ }^{25}$; b) extinguirlo, unilateralmente, en los casos especificados en la ley ${ }^{26}$; c) fiscalizar su ejecución; y d) aplicar sanciones ${ }^{27}$ motivadas por la inejecución total o parcial del ajuste ${ }^{28}$.

Todos esos poderes están hoy positivizados en los incisos del artículo 58 de la Ley n. ${ }^{\circ} 8.666 / 1993$, que aumenta la prerrogativa administrativa de

en los casos de servicios esenciales, ocupar provisoriamente bienes móviles, inmóviles, personal y servicios vinculados al objeto del contrato, en la hipótesis de la necesidad de investigar la precaución administrativa de faltas contractuales por el contratista, bien como en la hipótesis de recisión del contrato administrativo.

Y más allá de las prerrogativas del artículo 58, la Ley n. ${ }^{\circ}$ 8666/1993 define en el artículo 78.XV para los contratos administrativos una restricción a la cláusula de excepción del contrato no cumplido. En esos contratos es lícito que el contratista permanezca hasta noventa días sin recibir dinero por la prestación del servicio, sin derecho de invocar la excepción de contrato no cumplido y se encuentre obligado a prestar el servicio o continuar la obra o el suministro ${ }^{29}$. El proyecto de la Nueva Ley de Licitaciones mantiene dichas cláusulas exorbitantes, con pequeñas alteraciones que no mudan la esencia de las prerrogativas conferidas a la administración.

25 La alteración unilateral del contrato puede ser cualitativa o cuantitativa. Según el artículo 63 de la Ley n. ${ }^{\circ}$ 8666/1993, puede ser: a) unilateral por la Administración (cuando así exige el interés público que sobreviene al ajuste); o b) por consenso.

26 La recisión unilateral del contrato ocurre por anulación (un deber de la Administración) o derogatoria (en el contrato de concesión hay también traspaso). Así como en la derogatoria, el traspaso se dice respecto a la lógica de la conveniencia y oportunidad. Ocurre cuando algún hecho sobreviniente así lo justifica, con base en el interés público. El artículo 49 de la Ley $n .^{\circ} 8666 / 1993$ indica que habrá indemnización.

27 La aplicación de sanciones ocurre desde la más grave hasta la menos grave: a) declaración de idoneidad, b) suspensión del derecho de licitar, c) multa/ejecución de garantía, y d) advertencia. Es posible aplicar acumulativamente las sanciones. La medida para la aplicación de las sanciones es por el régimen, visto que no hay tipicidad, para la aplicación de esas sanciones. Para sanciones más graves, es necesario dolo o mala fe del agente (interpretación que se deriva de la lectura de los artículos 87. .IV y 88 de la Ley n. ${ }^{\circ} 8666 / 93$.

28 Celso Antônio Bandeira de Mello, Curso de Direito Administrativo, 33. ${ }^{a}$ ed., São Paulo: Malheiros, 2016, p. 631.

29 Ley n. ${ }^{\circ} 8.666 / 93$, artículo 78: "Constituem motivo para rescisão do contrato: [...]XV. o atraso superior a 90 (noventa) dias dos pagamentos devidos pela Administração decorrentes de obras, serviços ou fornecimento, ou parcelas destes, já recebidos ou executados, salvo em caso de calamidade pública, grave perturbação da ordem interna ou guerra, assegurado ao contratado o direito de optar pela suspensão do cumprimento de suas obrigações até que seja normalizada a situação". 
La lógica detrás de eso estaría en la superioridad de la Administración justificada en la relevancia colectiva de sus intereses contractuales. En ese sentido, José dos Santos Carvalho Filho, después de analizar la relación de igualdad entre partes en contratos privados, afirma que lo

mismo no pasa con los contratos administrativos, y eso es explicable por el hecho de que ellos están orientados a alcanzar un fin útil para la colectividad y, más allá de eso, de ellos participa la propia administración. Es lógico, entonces, que en el conflicto entre los intereses del particular contratado y del Estado contratante tengan que prevalecer los que pertenecen a este último ${ }^{30}$.

Pero esa noción, muy reiterada, no es compatible con los tratados de derechos humanos firmados por Brasil y por buena parte de los países integrantes del SIDH. Aunque se admita que "toda las cuotas firmadas por la Administración pública se someten al régimen jurídico administrativo en mayor o menor intensidad" ${ }^{\prime \prime 1}$, no es esencial que el contrato administrativo esté caracterizado por un régimen de prerrogativas para atender el interés público. Esa no es una nota característica del contrato o algo que lo desfigure como integrante de la especie de lo "administrativo". Antes que nada, el contrato administrativo es un acuerdo de voluntades que contiene lo pactado entre el particular y la Administración ${ }^{32}$, y es esta la única noción compatible con la lógica de los tratados de derechos humanos y con el paradigma de la convencionalidad. Esto, porque dicha lógica deconstruye la figura del Estado como titular de prerrogativas frente a los particulares, para darle el aspecto de una institución creada para atender los derechos sociales. El Estado existe para los ciudadanos, y no al contrario. Tal conclusión, apoyada en el paradigma convencional de los derechos humanos, refuerza la idea de que ni siquiera los acuerdos que el Estado firma por medio de su Administración deben tener como elemento esencial prerrogativas.

30 José dos Santos Carvalho Filho, óp. cit., p. 188.

31 Romeu Felipe Bacellar Filho, Direito Administrativo e o novo Código Civil, Belo Horizonte: Fórum, 2007, p. 184.

32 Fernando Dias Menezes de Almeida formula como nadie la explicación teórica de lo que aquí se busca decir: "Com efeito, do ponto de vista estrutural, reduzindo-se o contrato à sua essência substancial, àquilo que permite identificá-lo e distingui-lo das outras coisas, tem-se a existência do acordo de vontades entre partes diversas com o objetivo de criar uma situação jurídica individual. [...] Por outro lado, da perspectiva funcional, a essência substancial do contrato reside em ser técnica de pacificação social, por meio do respeito à palavra consensualmente dada, garantindo-se a confiança dela decorrente. Outra função que se queira apontar, no caso, p. ex., ao contrato administrativo, como a de supostamente garantir o interesse público mediante instrumentos de ação unilateral, consistindo em prerrogativas de uma das partes, não está presente somente nos contratos - $e$, aliás, imposições unilaterais, em princípio, parecem estranbas aos mecanismos contratuais". Fernando Dias MeneZES De Almeida, Contrato Administrativo, São Paulo: Quartier Latin, 2012, pp. 82-83. 
A partir del momento en que los tratados de derechos humanos se tornan fuente privilegiada del derecho administrativo, inequívocamente renuevan el entendimiento respecto de las prerrogativas conferidas al Poder Público para su actuación ${ }^{33}$. Así, el paradigma vivenciado por el derecho administrativo renovado por los tratados de derechos humanos también es consensual. Vivian Lima López Valle, al tratar las prerrogativas de la Administración pública en los contratos administrativos, resalta la redimensión de aquellas y la alteración del paradigma autoritario de la disciplina jurídica en estudio. El régimen jurídico administrativo se pauta actualmente por el "consensualismo y la negociación, como una dialéctica entre Estado-sociedad cada vez más abierta a la realización de acuerdos y de disposición de intereses ${ }^{\prime \prime 34}$. Cualquier posición doctrinaria, legal o jurisprudencial defensora de una supremacía autoritaria de la Administración pública (y no del interés público) en materia de contratación pública choca con los principios que rigen los tratados internacionales de derechos humanos asumidos por Brasil.

La incompatibilidad teórica evidenciada es soportada por los millones de particulares que firman contratos con la Administración y se encuentran con defectos o resistencias por parte del Estado contratante. Cuando se percibe que la aplicación de la teoría falla en la principal función del contrato, que es garantizar el cumplimiento de la palabra empeñada ${ }^{35}$, es porque algo errado hay con la misma ${ }^{36}$.

En cuanto a la fórmula para garantizar la mejor prestación del servicio público, la previsión legal de cláusulas exorbitantes preserva su sentido, esto es, deben ser orientadas a la atención adecuada del ser humano en aquellas

33 Pablo Ángel Gutiérrez Colantuono, El derecho administrativo argentino y su desafío frente al régimen americano de derechos bumanos. Derecho Administrativo Iberoamericano: 100 autores en homenaje al postgrado de Derecho Administrativo de la Universidad Católica Andrés Bello, t. I, Caracas: Ediciones Paredes, 2007, p. 145.

34 Vivian Lima López Valle, "Autoridade e consenso nos contratos administrativos: um reposicionamento do regime jurídico contratual brasileiro à luz da doutrina europeia dos contratos administrativos", en Luiz Alberto Blanchet, Daniel Wunder Hachem y Ana Claudia Santano, (coords.), Eficiência e ética na Administração Pública, Curitiba: Íthala, 2015, p. 319.

35 Romeu Felipe Bacellar Filho, en la defensa del contrato como categoría perteneciente al derecho, y no particularmente al derecho público o privado, afirma que "os Princípios Lex Inter Partem e Pacta Sunt Servanda fazem com que o contrato seja Lei entre as partes, e que estas, devidamente ajustadas, observem o que foi pactuado". ROMEu Felipe BACELLAR FilHo, "O contrato administrativo no Brasil", Revista do Advogado, n. ${ }^{\circ}$ 107, 2009, p. 157.

36 "Pela perspectiva funcional, a teoria do contrato administrativo, bem como seu reflexo no Direito positivo - é o caso do Brasil - são potencialmente desestabilizadoras da finalidade do contrato como instrumento de pacificação social decorrente do respeito à confiança derivada do consenso das partes. Com efeito, a desconfiança é inerente à ideia de que a Administração tenba, por força de lei e independentemente do prévio consentimento das partes, prerrogativas de ação unilateral que operem em sentido contrário do respeito ao que consensualmente foi estabelecido numa relação contratual". FeRnANDo Dias MenEZes de AlmeidA, óp. cit., pp. 323-324. 
situaciones de la vida cuya necesidad de provisión estatal de bienes y servicios es inexcusable. No obstante, en otros ámbitos de la contratación, las prerrogativas administrativas de rescisión, alteración unilateral y suspensión temporal del pago no son pertinentes. Empíricamente se observa, en verdad, que ellas desestimulan las contrataciones y/o las encarecen en valores mayores al del precio de mercado ${ }^{37}$. Basta imaginar la situación hipotética en que sea natural que el particular contratado incluya en sus costos los riesgos de una probable suspensión de pagos por noventa días, en lo mínimo, por parte de la Administración contratante ${ }^{38}$. Es obvio que indirectamente eso perjudica los ciudadanos, principales interesados en la manutención del patrimonio público y la continuidad de la buena actividad administrativa. En síntesis, la teoría del contrato administrativo que destaca las "cláusulas exorbitantes" como esencia de la especie, no se sustenta más en el paradigma de la convencionalidad ${ }^{39}$.

Esto tampoco sirve para afirmar que las cláusulas exorbitantes pueden ser mantenidas bajo el argumento de que siempre la garantía de ser indemnizado estará reservada al particular ${ }^{40}$. Esa explicación no es válida cuando se cuenta

37 Sobre el aumento de los costos de transacción provocados por las cláusulas exorbitantes en contratos administrativos, bien como sobre una propuesta de utilización de las prerrogativas contractuales de modo discrecional, depende del juicio de oportunidad y conveniencia de la Administración para utilizarlas. Cfr. Diogo de Figueiredo Moreira Neto, "O futuro das cláusulas exorbitantes nos contratos administrativos", en Alexandre Santos de Aragão y Floriano de Azevedo Marques Neto (coords.). Direito Administrativo e seus novos paradigmas, Belo Horizonte: Fórum, 2008, pp. 571-592.

38 La comprobación cabal de la afirmación carece de estudios empíricos.

39 Es de destacar la entrevista concedida por Marçal Justen Filho al sitio web Consultor Jurídico, en la cual utiliza interesante analogía para para exponer los defectos del régimen contractual administrativo: "Esse é o problema a ser enfrentado. E enfrentar esse problema significa o Estado assumir democraticamente a respeitabilidade dos direitos e interesses dos particulares com quem contrata. Dou um exemplo simples: imagine você chegar numa loja de eletrodomésticos e dizer 'quero levar aquele televisor, mande entregar na minha casa. Pagarei 30 dias depois, se eu quiser. Pode ser que eu prefira não pagar'. Quem venderia um televisor a você nessa situação? Ninguém. Se alguém vendesse, cobraria um preço muito mais elevado. No Brasil, a Administração Pública é titular de competências extraordinárias, inúteis e desnecessárias na maior parte dos casos. As contratações serão necessariamente mais onerosas. O problema não éa licitação, mas as regras de Direito Contratual". MarÇAL Justen FILHO, Entrevista concedida a Renata Teodoro, Consultor Jurídico, 3 de agosto de 2014. Disponible en línea: http://www. conjur.com.br/2014-ago-03/entrevista-marcal-justen-especialista-direito-administrativo [consultado el 18 de diciembre de 2019].

40 En ese sentido se posiciona Alice Gonzales Borges. Contraria a la extinción de las cláusulas exorbitantes en nombre de la protección del interés público, la autora manifiesta lo siguiente en favor de prerrogativas en los contratos administrativos en general: "Vimos que, em nosso ordenamento, sobretudo a partir da Constituição de 1988, tais cláusulas vêm sofrendo limites e abrandamentos, de tal modo que as imposições ditas imperativas e autoritárias são compensadas com a previsão legal da preservação do equilibrio econômico-financeiro entre os encargos dos contratados e a sua adequada remuneração, bem como por meio de cláusulas de adequada proteção aos direitos dos administrados". ALICE GONZALES BorGES, "Considerações sobre o futuro das cláusulas exorbitantes nos contratos administrativos", Revista do Advogado, n. ${ }^{\circ}$ 107, 2009, p. 23. 
con un sistema de precauciones fallido como el que opera en la mayor parte de los entes federados brasileros ${ }^{41}$. Frente a ese cuadro fáctico y jurídico, las reglas legales que prevén prerrogativas contractuales a la Administración en todo y cualquier contrato administrativo son reglas contrarias a la lógica convencional pro persona, por cuanto en un último análisis invierten su razón de ser y son contrarias al interés público y al mejor interés del ser humano para quien el Estado existe.

La seguridad jurídica es un derecho de los seres humanos en relación. El contrato administrativo permeado de cláusulas exorbitantes en situaciones jurídicas que no las justifican atenta contra la seguridad de las relaciones jurídicas y coloca a los agentes privados en un estado constante de alerta, lo que es perjudicial para los ciudadanos en la punta de la cadena de la acción administrativa. Definitivamente, en materia de contratos administrativos, los tratados de derechos humanos deben ser invocados no específicamente en sus reglas, pero en su lógica en privilegio del ser humano. Todas las leyes que establecen prerrogativas administrativas en los contratos públicos, sin considerar las especificidades de cada relación contractual administrativa, requieren ser revisadas ${ }^{42}$. Es decir, leyes que determinan prerrogativas contractuales para la Administración en cualquier contrato y de forma general son incompatibles con la convencionalidad ${ }^{43}$. Cualquier relación asimétrica entre Estado y el ciudadano

41 En Brasil, las deudas del Estado son pagas por el sistema de precatorios, en que el Poder Judicial insta al Poder Ejecutivo al pago después del transito en juicios de procesos judiciales y la finalización de pedidos de cumplimiento de sentencias. El sistema se encuentra ya hace tiempos con atrasos que superaban, en algunos casos, décadas.

42 Fernando Dias Menezes de Almeida da ejemplos de contratos de derecho privado, como el mandato, comodato, transporte y empeño, para, así como cuando ejemplifica la resolución por onerosidad excesiva prevista en el artículo 478 del Código Civil, afirmar que nada hay de particular en los contratos administrativos en lo que se refiere a algunas prerrogativas garantizadas a alguna de las partes del contrato. Afirma el autor de forma conclusiva: "Em suma, o que se quer sustentar é que, seja em face de interesses públicos, seja em face de interesses privados, um regime contratual que preveja determinados poderes de ação unilateral a uma das partes, levando ao que se pode chamar de mutabilidade contratual, deve decorrer das circunstâncias que concretamente envolvem o objeto da prestação, mas não, a priori e em abstrato, da natureza pública ou privada dos interesses em questão". Fernando Dias Menezes de Almeida, óp. cit., p. 335.

43 Lo que no significa que la legislación no pueda prever prerrogativas para ciertos contratos que sirvan como instrumento de acción pública, ya que en todo caso deberá ser ejercitado de forma motivada por el administrador, de acuerdo con el objeto contractual en cuestión. Lo que caracteriza un contrato como administrativo no es, entonces, el hecho de tener inherente a él cláusulas exorbitantes, pero sí sufrir incidencia del régimen jurídico-administrativo que puede en el interés publico auto ejecutar algunas cláusulas (tal como se admite en algunos contratos privados) como por ejemplo en la revocatoria del mandato. Fernando Dias Menezes de Almeida indica: "Desse modo, nem todo contrato administrativo comportaria tais prerrogativas, mas somente os contratos que tivessem por objeto algo que, por sua natureza [...] independentemente de execução via contrato, exigisse permanente possibilidade, a ser dado pelo Direito positivo, de modificação por parte da Administração, com o objetivo de se atender ao interesse público. E ainda: os que comportassem, pudessem fazê-lo em diversos graus. [...] Desta opção de associar as prerrogativas da Administração ao objeto, e não 
(y aquí también se consideran los ciudadanos unidos en el contrato social para emprender una actividad económica $)^{44}$, no justificada de forma expresamente motivada en el mejor interés de la sociedad ${ }^{45}$, es anticonvencional por ir en contravía del principio de isonomía. Se recuerda, como afirman Luiz Flávio Gomes y Valerio de Oliveria Mazzuoli en sus comentarios al artículo 24 del Pacto de San José de Costa Rica, que las "discriminaciones injustificadas y no razonables a las personas atentan contra la Convención Americana y merecen la represión de la justicia internacional" ${ }^{\prime 46}$. Esto es, las reglas legales abstractas de prerrogativas injustificadas para todo y cualquier contrato administrativo afrontan todavía el principio de igualdad previsto en diversos tratados internacionales de los que Brasil es signatario.

Solamente cuando un régimen de prerrogativas fuese funcionalmente adecuado al interés público (lo que no se puede averiguar abstractamente, sino siguiendo los diversos objetos de los contratos administrativos) es que se justifica la existencia de un régimen privilegiado de la Administración en el contrato; lo que de resto ya está intrínseco a la idea del régimen jurídico-administrativo y autorizado por el artículo 30 del Pacto de San José de Costa Rica ${ }^{47}$. Lo anterior se ejemplifica del siguiente modo: si es deseable que en los contratos de concesión de servicio público la ley prevea (siempre después de la resolución consensual de eventuales conflictos $)^{48}$ el derecho de alterar unilateralmente el

ao contrato - ou seja, a qualduer contrato em que a Administração tome parte-, decorre a inadeduação de que se dê um mesmo tratamento, em termos de uma lei geral, a todos os contratos que tenbam a Administração como parte". Ibíd., pp. 384-385.

44 Como afirma Juan M. González Moras, los tratados de derechos humanos provocan una alteración en el relacionamiento de las normas jurídicas nacionales e internacionales, de modo que prevalecerá la norma más proteccionista para la persona, inclusive para las personas jurídicas cuando fuese el caso. JuAn M. GonZÁlez Moras, "La internacionalización del derecho administrativo argentino", Revista Argentina del Régimen de la Administración Pública, n. ${ }^{\circ} 348,2007$, p. 17.

45 En tesis innovadora, Vivian Valle defiende criterios objetivos para la utilización de las prerrogativas, que según ella no deben valer abstractamente para todos los contratos. Según la autora, en superación al modelo de administración autoritario, las prerrogativas contractuales deben ser aplicadas apenas subsidiariamente en caso de: a) urgencia; b) excepcionalidad $_{i}$ ) residualmente a las resoluciones consensuales; o d) justificadamente, cuando se compruebe los beneficios a las finalidades contractuales. ViviAN LiMA LÓPEZ VALLE, Contratos administrativos e um novo regime jurídico de prerrogativas contratuais na Administração Pública contemporânea, Belo Horizonte: Fórum, 2018, p. 242-244).

46 Luiz Flávio Gomes y Valerio de Oliveira Mazzuoli, óp. cit., p. 214.

47 Convención Americana sobre Derechos Humanos, artícuo 30: "Alcance de las restricciones. Las restricciones permitidas, de acuerdo con esta Convención, al goce y ejercicio de los derechos y libertades en ella reconocidos, no pueden ser aplicados sino de acuerdo con leyes que fuesen promulgadas por motivo de interés general y con el propósito para el cual hubieren sido establecidas".

48 "O que se propõe é uma condição de autoridade subsidiária a uma postura negocial prévia". VIVIAN LiMA López Valle, Contratos administrativos..., óp. cit., pp. 255. 
objeto del contrato o rescindirlo (por cuenta de la mutabilidad intrínseca a las condiciones materiales de la prestación de la actividad del servicio público), en los contratos de compra y venta de mercaderías no se justifica la posibilidad de alteración unilateral del objeto contractual o la rescisión. En este segundo caso, la única justificación para facultar la alteración unilateral es la falta de planeación de la Administración en la fase precontractual en cuantificar de modo óptimo lo que es necesario adquirir ${ }^{49}$.

El ejemplo trata de política legislativa, pero puede ser analizado a partir de la perspectiva de los tratados de derechos humanos para concluir que la legislación que prevea abstractamente la cláusula de alteración o rescisión unilateral en los contratos de compra y venta de mercaderías por la Administración sería anticonvencional por violación al principio de igualdad y no discriminación (artículo 24 de la Convención Americana). Desde cualquier ángulo, las "cláusulas exorbitantes no pueden ser entendidas como privilegios de la Administración pública dentro de un Estado democrático de derecho" ${ }^{\prime 50}$.

Nada impide, por cierto, que la Administración acuerde con el particular esos derechos en el contrato. No obstante, la previsión en abstracto de estos en la ley para cualquier clase de contrato constituye una prerrogativa legal anti-isonómica que, más allá de ser contraria a los tratados de derechos humanos, da paso al entendimiento de una Administración pública por encima de los particulares en sus relaciones contractuales. Esa perspectiva anacrónica va, por tanto, en contravía de los parámetros de la actuación convencional de la Administración pública. Así, es anticonvencional afirmar que en los contratos administrativos en caso de "conflicto entre los intereses del particular contratado y del Estado contratante tengan que prevalecer los pertenecientes a este último" ${ }^{\prime \prime 1}$. Al final, si el principio pro persona previsto en innumerosos tratados de derechos humanos afirma el deber de la Administración de "aplicar la norma más beneficiosa para el particular, inclusive aquella que sea mas perjudicial a la Administración" ${ }^{\prime \prime 2}$, es contrario al principio de afirmar en abstracto que conflictos contractuales deben ser siempre decididos en favor del Poder Público. Estos conflictos deberán ser decididos conforme las reglas jurídicas aplicables, en favor de quien tenga derecho en el caso concreto. Si la solución jurídica implica un perjuicio para la Hacienda Pública, que transgrede ilegalmente sus

49 "Grande parte das dificuldades e dos problemas enfrentados pela Administração Pública ao longo da licitação e durante a execução do contrato pode ser evitada por meio da atuação cuidadosa e diligente nessa etapa interna. Todas as atividades preliminares destinam-se a evitar surpresas, desperdício de tempo e de recursos públicos e início de projetos inviáveis". MarÇal Justen Filho, Curso ..., óp. cit., p. 479.

50 Vivian Lima López Valle, "Autoridade e consenso...", óp. cit., p. 323.

51 José dos Santos Carvalho Filho, óp. cit., p. 188.

52 Gregorio FlaX, "La sumisión del derecho administrativo a los tratados internacionales de derechos humanos", Revista de la Asociación Internacional de Derecho Administrativo, n. ${ }^{\circ}$ 16, 2014 , p. 382 . 
deberes contractuales, nada de anticonvencional habrá en eso. Al contrario, estará conforme a la regla convencional que protege el derecho de propiedad en el artículo 21.2 de la Convención Americana ${ }^{53}$.

Esa alteración de la perspectiva en que se encuentra posicionado el contrato administrativo se inserta en la onda reciente de la contractualización de las actividades administrativas, iniciada con la Ley de Concesiones (Ley n. $\left.{ }^{\circ} 8.987 / 1995\right)$, y que encuentra en la Ley de Asociaciones Público-Privadas (Ley n. ${ }^{\circ} 11.079 / 2004$ ) la más fiel representación de cómo por medio de los contratos se opta por la prestación de servicios públicos y la efectivación de los derechos humanos ${ }^{54}$.

\section{RÉGIMEN DE LOS SERVICIOS PÚBLICOS Y LA CONVENCIONALIDAD: BASE NORMATIVA SUPRACONSTITUCIONAL}

Existen interacciones importantes entre el derecho administrativo y los tratados de derechos humanos en materia de servicios públicos ${ }^{55}$. El breve análisis emprendido en este artículo abarca el concepto de servicio público en sentido estricto ${ }^{56}$, o incluso el de servicios públicos económicos, especie del género actividad económica ${ }^{57}$. Diversas son las definiciones del concepto. Se emplea, para efectos de esta investigación, aquella que lo coloca entre actividad de prestación de bienes y/o servicios a la colectividad por el Estado o quien haga sus veces, que sean definidos como esenciales para la satisfacción

53 Convención Americana sobre Derechos Humanos, artículo 21: "Derecho a la propiedad privada. [...]2. Ninguna persona puede ser privada de sus bienes, salvo mediante el pago de una indemnización justa, por motivo de utilidad pública o de interés social en los casos y en la forma establecidos por la ley".

54 Para una visión general de la actuación administrativa mediante contratos, cfr. LuIs ALBERTO Hungaro, "As transformações da gestão pública e o governo por contratos: a contratualização das políticas públicas", Revista Digital de Direito Administrativo, vol. 3, n. ${ }^{\circ} 2,2016$, pp. 367-383.

55 Normas internacionales de derechos humanos influencian en los servicios públicos como "técnica de coesão e igualação social devida pelos Estados nacionais". Son ejemplo trabajados en la Declaración Americana sobre Derechos y Deberes del Hombre, artículo Xxxvi, en la Convención Americana, en los artículos 1.1, 2 y 24; y en el protocolo de San Salvador, en el artículo 11.1. JuAn M. GONZÁlEZ MORAS, "La internacionalización del derecho administrativo argentino", Revista Argentina del Régimen de la Administración Pública, n. ${ }^{\circ} 348,2007$, p. 42.

56 La Ley de Defensa de los Derechos de los Usuarios del Servicio Público, no es lo que se busca detallar en las líneas que se siguen. Sin excluir la utilidad del concepto para los fines al que la ley se destina, no es de ella que se parte para las consideraciones de ese trabajo sobre el tema. Para registrar, el concepto previsto en el artículo 2, inciso II es el siguiente: "servicio público-actividad administrativa o de prestación directa o indirecta de bienes o servicios a la población, ejercida por el órgano o entidad de la Administración pública".

57 Cfr. en ese sentido a Eros Roberto Grau, A ordem econômica na Constituição de 1988, 17. ${ }^{\text {a ed. }}$ São Paulo: Malheiros, 2015, pp. 100-101. 
de las necesidades de la colectividad y que por ese motivo no pueden quedar a merced exclusiva del mercado para ser producidos/prestados. Por esto, entre las diferentes aproximaciones posibles, interesa la del servicio público como técnica de garantía de realización de los derechos humanos. Y más específicamente, en lo que atañe al derecho administrativo, como instituto jurídico en el que "se describe la prestación de una actividad que orienta la satisfacción de las necesidades públicas" ${ }^{158}$.

La prestación de servicios públicos por el Estado o los delegatarios, de importancia presumida para la materialización del desarrollo nacional ${ }^{59}$, tiene soporte constitucional en el artículo 175 de la Constitución brasilera ${ }^{60}$. La previsión constitucional de los servicios públicos cotejada con el artículo $6 .{ }^{\circ}$ de la Ley $n .^{\circ} 8.987 / 1995$ constituye el derecho fundamental al servicio público adecuado, cuyos contornos fueron delineados por Adriana da Costa Ricardo Schier en el régimen jurídico integrador de la universalidad de la prestación, el régimen de las tarifas y la continuidad del servicio ${ }^{61}$. En otros países integrantes del SIDH, como Colombia, también gana importancia el régimen jurídico de los servicios públicos. Conforme lo enseña Aníbal Zárate Pérez, con relación a los servicios públicos domiciliarios se puede hablar de un régimen especial en la prestación. Según el autor, con el fin de "asegurar su prestación eficiente a todos los habitantes del territorio nacional, aquel [el Estado] mantiene las funciones de regulación, vigilancia y el control sobre su prestación"62.

No sorprende que sea así en más de un país, pues más allá de un fundamento constitucional en cada Estado, la figura del servicio público tiene base

58 JuAn M. GonZÁlez Moras, "El régimen del servicio público en los ordenamientos públicos globales", en Edgardo Tobías Acuña et al., Estudios de derecho público, Buenos Aires: Asociación de Docentes - Facultad de Derecho y Ciencias Sociales - UBA, 2013, p. 831.

59 Es interesante señalar aquí las lecciones de Emerson Gabardo, para quien el Estado y la iniciativa privada comparten funciones en pro del desarrollo, lo que excluye la noción replicada del principio de subsidiariedad. En las palabras del autor: "A ordem ecônomica encontrada na Constituição de 1988 não consagrou a subsidiariedade como princípio [...]. O processo de desenvolvimento previsto é de caráter centralizado e estabelece competências próprias para o Estado e para cada um dos entes, além de regulamentação específica que é direcionada à iniciativa privada". EMERSON GABARDO, Interesse público e subsidiariedade: o Estado e a sociedade civil para além do bem e do mal, Belo Horizonte: Fórum, 2009, pp. 246-247.

60 Constitución Federal de Brasil, artículo 175: "Incumbe al poder público, en la forma de la Ley, directamente o bajo el régimen de concesión o licencia, siempre a través de licitación, la prestación de servicios públicos".

61 AdRIANA DA COSTA RICARDO SCHIER, Serviço público: garantia fundamental e cláusula de proibição de retrocesso social, Curitiba: Íthala, 2016.

62 Aníbal Zárate PéreZ, "La especialidad relativa de la potestad sancionadora en materia de servicios públicos domiciliarios", en Alberto Montaña Plata y Jorge Iván Rincón Córdoba (eds.), El poder sancionador de la administración pública: discusión, expansión y construcción, Bogotá: Universidad Externado de Colombia, 2018, p. 780. 
supraconstitucional ${ }^{63}$. En la Declaración Universal de los Derechos Humanos consta en el artículo XXI.2 que "todo ser humano tiene igual derecho de acceso al servicio público de su país". En la Declaración Americana de Derechos Humanos, el artículo 36 define: "Toda persona tiene el deber de pagar los impuestos establecidos por la ley para la manutención de los servicios públicos". Existe, así, un deber del Estado de prestar servicios públicos siguiendo las normas internacionales del derecho internacional de los derechos humanos.

Igualmente, para quien lucha por reconocer la fuerza normativa de las declaraciones internacionales o no las considera jus cogens, vale la pena subrayar que en el SiDH el Protocolo del Salvador, vigente en Brasil con fuerza normativa incuestionable, prevé en el artículo 11.1 que "Toda persona tiene derecho a vivir en un medio ambiente sano y a contar con los servicios públicos básicos". El sentido de esas normas sobre servicios públicos en convenciones internacionales de derechos humanos, según Juan Martín González Moras, es consolidar en el plano internacional la figura "como una técnica de cohesión e igualdad social ${ }^{64}$ debida por los Estados nacionales, que, por su parte, implica, correlativamente, el deber de organizar su prestación, bien como eventualmente, contribuir para su manutención"65. En otras palabras, el servicio público, antes de ser instituto jurídico de derecho administrativo interno, es "una técnica de garantía de los derechos humanos" ${ }^{166}$ con origen en una normativa internacional.

Más de un documento internacional vinculante para Brasil identifica el deber de prestación de servicios públicos. Entre ellos se puede citar la Declaración Universal de los Derechos Humanos de 1948 (artículo 25.1) ${ }^{67}$; la Convención sobre la Eliminación de todas las Formas de Discriminación contra la Mujer

63 Acerca de la supraconstitucionalidad relativa a los tratados de derechos humanos, cfr. FeLIPE KlEIN GuSSOLI, "Hierarquia supraconstitucional relativa dos tratados internacionais de direitos humanos", Revista de Investigações Constitucionais, vol. 6, n. ${ }^{\circ}$ 3, 2019.

64 Lo que de resto es compatible con los artículos 1 y 24 de la Convención Americana sobre Derechos Humanos en lo que dice respecto al principio de igualdad y no discriminación. El servicio público es deber del Estado, "uma das ações positivas que o mesmo se encontra obrigado a desenvolver para garantir a efetividade dos direitos reconbecidos pelo Direito Internacional dos Direitos Humanos e, correlativamente, pelos ordenamentos constitucionais nacionais". JuAN M. GonZÁlez MORAS, "El concepto de servicio público...", óp. cit., p. 425.

65 Ibíd., p. 412.

66 Según Salomoni, esa técnica se desdobla en: a) "técnica de igualação do disfrute dos bens materiais e culturais produzidos por uma sociedade e para todos os indivíduos que a compõem"; b) "técnica de igualdade de tratamento jurídico e político"; y c) "técnica de integração social". JorGe LuIs SALOMONI, Teoría general de los servicios públicos, Buenos Aires: Ad-hoc, 2004, pp. 326-327.

67 Declaración Universal de los Derechos Humanos, artículo. 25.1: "Toda persona tiene derecho a un patrón de vida capaz de asegurar a sí mismo y a su familia, salud y bienestar, inclusive alimentación, vestuario, habitación, cuidados médicos y los servicios sociales indispensables, el derecho a la seguridad en caso de desempleo, enfermedad, invalidez, viudez, vejez u otros casos de pérdida de los medios de subsistencia en circunstancias fuera de su control". 
(artículo 14.2) ${ }^{68}$; la Convención sobre la Eliminación de Todas las Formas de Discriminación Racial (artículo 5) ${ }^{69}$ y la Convención sobre los Derechos de los Niños (artículo 24). En el ámbito regional latinoamericano, se cita la promulgación del Protocolo de Montevideo sobre el Comercio de Servicios del Mercosur por el Decreto n. ${ }^{\circ} 6480$ del 11 de junio de 2008. El protocolo regula aspectos de prestación de una serie de servicio en el Mercosur, entre ellos, el servicio público de transporte y de telecomunicaciones, de gran importancia para los derechos fundamentales humanos.

El análisis de esta normatividad hace que también sea necesario aproximar el derecho administrativo regional al derecho internacional de los derechos humanos ${ }^{70}$. En conjunto, las normas internacionales sobre servicios públicos deconstruyen cualquier tentativa de erradicación legal o constitucional del instituto en los ordenamientos que las incorporan ${ }^{71}$. Esas previsiones en tratados hacen del servicio público un derecho humano social, no sujeto a la prestación discrecionaria de los Estados ${ }^{72}$, opinión expresada en el voto concurrente del juez Antonio Augusto Cançado Trindade en la Opinión Consultiva n. ${ }^{\circ}$ 18/2003

68 Decreto n. ${ }^{\circ}$ 4.377/2002, artículo 14.2. "Os Estados-partes adotarão todas as medidas apropriadas para eliminar a discriminação contra a mulber nas zonas rurais, a fim de assegurar, em condições de igualdade entre bomens e mulberes, que elas participem no desenvolvimento rural e dele se beneficiem, e em particular assegurar-lhes-ão o direito $a: b$ ) ter acesso a serviços médicos adequados, inclusive informação, aconselhamento e serviços em matéria de planejamento familiar, d) obter todos os tipos de educação e de formação, acadêmica e não-acadêmica, inclusive os relacionados à alfabetização funcional, bem como, entre outros, os benefícios de todos os serviços comunitários e de extensão, a fim de aumentar sua capacidade técnica, b) gozar de condições de vida adequadas, particularmente nas esferas da babitação, dos serviços sanitários, da eletricidade e do abastecimento de água, do transporte e das comunicações".

69 Decreto n. ${ }^{\circ} 65.810 / 1969$, artículo 5: "De conformidade com as obrigações fundamentais enunciadas no artigo 2, Os Estados Partes comprometem-se a proibir e a eliminar a discriminação racial em todas suas formas e a garantir o direito de cada uma à igualdade perante a lei sem distinção de raça, de cor ou de origem nacional ou étnica, principalmente no gozo dos seguintes direitos: e) direitos econômicos, sociais culturais, principalmente: iv) direito à saúde pública, a tratamento médico, à previdência social e aos serviços sociais, v) direito a educação e à formação profissional, $f$ ) direito de acesso a todos os lugares e serviços destinados ao uso do publico, tais como, meios de transporte, hotéis, restaurantes, cafés, espetáculos e parques".

70 En las palabras precisas de Enrique Rojas Franco, las "relações entre os povos se estreitaram em virtude da facilidade de comunicação e de transporte principalmente, o que deu lugar a que regulamentem, por meio de tratados internacionais, muitas de las de caráter administrativo". ENRIQUE ROJAS FRANCO, "Los tratados internacionales como fuente de derecho", en Jaime Rodríguez-Arana Muñoz (coord.), Fuentes del derecho administrativo: tratados internacionales, contratos, como regla de derecho, jurisprudencia, doctrina y precedente administrativo. Buenos Aires: RAP, 2010, p. 298.

71 "[...] o serviço público foi delineado, no marco dos ordenamentos internacionais de direitos bumanos, como uma técnica de coesão e igualação social devida pelos Estados nacionais que, por sua parte, implica, correlativamente, no dever de organizar sua prestação e, quando apropriado, contribuir para sua sustentação". Juan M. González Moras, "El régimen del servicio público en...", óp. cit., p. 852.

Juan M. González Moras, "El concepto de servicio público...", óp. cit., p. 417-418. 
de la Corte IDH, en donde se insiste en el deber del Estado de prestar servicios públicos, criticando la entrega de la totalidad de las actividades al mercado ${ }^{73}$.

La previsión del derecho al servicio público en declaraciones y tratados internacionales retira del derecho administrativo interno de cada país la base de existencia de la institución y descarta tentativas de excluirlo como derecho inherente a los sistemas jurídicos nacionales que se sujetan a la normatividad internacional ${ }^{74}$. Una vez reconocido como derecho convencional, es exigible su prestación por la Administración y se genera una responsabilidad internacional en caso de falla en el cumplimiento de la obligación internacional de prestar servicios públicos ${ }^{75}$. De hecho, el principio de no discriminación del artículo 24 del Pacto de San José de Costa Rica, tal como es interpretado por la Corte IDH, obliga a los Estados a vigilar y sancionar a terceros prestatarios que mantengan o favorezcan situaciones de desigualdad ${ }^{76}$. En esos casos de contratos de concesión, contrario a lo que rezan los contratos administrativos de otra especie, la "cláusula exorbitante" de fiscalización contractual es plenamente legítima y de acuerdo con los tratados internacionales de derechos humanos ${ }^{77}$.

Los tratados de derechos humanos provocan un desplazamiento en la comprensión de la institución como una potestad estatal hacia la idea de un servicio que tiene como razón de ser la satisfacción de las necesidades de los usuarios $^{78}$. El derecho internacional de los derechos humanos define la razón de ser de toda la teorización del servicio público, la cual es propiciar al ciudadano el mejor de los mundos en aquello que la sociedad comprende como elemental para una vida digna. Como señala Celso Antonio Bandeira de Mello, en el servicio público "la figura estelar no es su titular ni el prestador de este,

73 Al tratar sobre la situación de los migrantes sin documentos en el mundo globalizado, el juez Cançado Trinidade hace constatar en su voto que: "Como circunstâncias agravantes, o Estado abdica de sua inescapável função social, e entrega irresponsavelmente ao mercado os serviços públicos essenciais (educação e saúde, entre outros), transformando-os em mercadorias às quais o acesso torna-se cada vez mais difícil para a maioria dos indivíduos. Estes últimos passam a ser vistos como meros agentes de produção econômica, em meio à triste mercantilização das relações bumanas". CORTE INTERAMERICANA DE Derechos Humanos, Opinión Consultiva n. ${ }^{\circ}$ 18/2003, Condición Jurídica y Derecho de los migrantes sin documentos. Publicada el 17 de septiembre de 2003. Voto concorrente del juez Antonio Augusto Cançado Trindade, § 17.

74 Jorge Luis Salomoni, "Impactos de los tratados de derechos humanos sobre el derecho adminstrativo argentino", en Jorge Luis Salomoni, Romeu Felipe Bacellar Filho y Domingo J. Sesin, Ordenamientos internacionales y ordenamientos administrativos nacionales: jerarquía, impacto $y$ derechos bumanos, Buenos Aires: Ad-hoc, 2006, p. 29.

75 Juan M. GonzálezZ Moras, "El régimen del servicio público...", óp. cit, p. 853.

76 Corte Interamericana de Derechos Humanos, Opinión Consultiva n. ${ }^{\circ}$ 18/2003, óp. cit., $\S 104$.

77 En rigor, fiscalizar el cumplimiento de un contrato no es prerrogativa de la Administración únicamente, pero derecho de cualquier contratante en contratos de cualquier naturaleza. Jorge Luis Salomoni, "Impactos de los tratados...", óp. cit., p. 28. 
pero sí el usuario"79. La influencia de los derechos humanos en materia de servicio público corresponde a la vista del ejercicio de esa actividad "no desde la óptica de las prerrogativas de la Administración o desde el poder del Estado, sino desde la perspectiva de los derechos de los usuarios ${ }^{180}$.

\section{RÉGIMEN DE CONCESIONES Y PERMISOS Y CONVENCIONALIDAD: PRIORIDAD AL USUARIO}

El servicio público está asociado al tema de los contratos administrativos, pues no es raro que el Estado delegue su prestación a los particulares, como expresamente está permitido por la regla del artículo 175 de la Constitución brasilera de 1988. En ese aspecto, el derecho internacional de los derechos humanos se centra en la relación entre Estado y/o delegatarios y usuarios ${ }^{81}$. En esa relación triangular, los concesionarios sustituyen el Poder Público. "Consigue el bono, pero enfrenta la carga del encargo" ${ }^{\text {"82. }}$

En el caso Ximenes Lopes vs. Brasil - primera condena internacional de esta nación en el SIDH por la muerte de Damião Ximenes Lopes. internado en una casa de rehabilitación siquiátrica privada en convenio al Sistema Único de Salud- la Corte IDH enfrentó directamente el tema de los servicios públicos, ocasión en que declaró la responsabilidad del Estado por un acto de entidades privadas que prestan servicios de titularidad estatal. El deber de garantizar los derechos humanos y de adecuar todas las estructuras estatales hacia la aplicación efectiva de los dispositivos convencionales, previsto en el artículo 2 del Pacto de San José, obliga a una vigilancia por parte del Estado y a reglamentar de forma adecuada de los servicios públicos ${ }^{83}$. Igualmente, en el caso Granier y otros (Radio Caracas Televisión) vs. Venezuela, la Corte IDH decidió que aplica la Convención Americana sobre Derechos Humanos al servicio público

79 Celso Antônio Bandeira de Mello, óp. cit., p. 705

80 Augusto Durán MarTíneZ, "Derechos de los usuarios de los servicios de interés económico general desde la perspectiva de los derechos humanos", $\mathrm{A}_{\&} \mathrm{C}$ - Revista de Direitos Administrativo \& Constitucional, n. ${ }^{\circ} 42,2010$, p. 30

81 Juan M. Gonzálezz Moras, "El régimen del servicio público...", óp. cit., p. 864.

82 Romeu Felipe Bacellar Filho, "Considerações críticas sobre as licitações e contratos administrativos", A\&C-Revista de Direitos Administrativo \& Constitucional, n. ${ }^{\circ} 14,2003$, p. 80.

83 "La prestación de servicios públicos implica la protección de bienes públicos, la cual es una de las finalidades de los Estados. Si bien los Estados pueden delegar su prestación, a través de la llamada tercerización, mantienen la titularidad de la obligación de proveer los servicios públicos y de proteger el bien público respectivo. La delegación a la iniciativa privada de proveer esos servicios, exige como elemento fundamental la responsabilidad de los Estados en fiscalizar su ejecución, para garantizar una efectiva protección de los derechos humanos de las personas bajo su jurisdicción y para que los servicios públicos sean provistos a la colectividad sin cualquier tipo de discriminación, y de la forma más efectiva posible". Corte Interamericana De Derechos Humanos, Caso Ximenes Lopes vs. Brasil, sentencia del 4 de julio de 2006, §96. 
de telecomunicaciones a cargo del Estado, dejando claro que derechos como el de la libertad de pensamiento y expresión (artículo 13 del Pacto de San José) son inherentes a la actividad del servicio público y que la prórroga de los contratos de concesión no se puede dar de modo arbitrario y desmotivado ${ }^{84}$ Hoy se destaca la postura activa de la Corte IDH en materia de servicios públicos, medio de satisfacción de derechos económicos, sociales y culturales ${ }^{85}$.

En las concesiones de servicios públicos existe una relación jurídico-administrativa entre el Estado concedente, el concesionario, el ente regulador ( $\mathrm{si}$ fuere el caso) y el usuario ${ }^{86}$. Los principales impactos de los tratados de derechos humanos se identifican en favor del usuario ciudadano en esa relación jurídica compleja y multipolar. En ese sentido, según Aníbal Zárate Pérez, la regulación estatal debe buscar un compromiso entre los intereses económicos y el interés público de los usuarios ${ }^{87}$.

En esa línea, la lógica de los derechos humanos asume que, frente a un eventual conflicto entre derechos de los prestadores de los servicios públicos y los usuarios, prevalecerá la norma o solución que atienda mejor al interés de esos últimos ${ }^{88}$. Desde la óptica de la prestación de los servicios públicos como derecho humano, la anulación administrativa o judicial de un permiso o concesión por ser desventajoso para los usuarios es plenamente posible, preservando el derecho de indemnización a los concesionarios y permisionarios (por respeto al derecho del artículo 21.2 de la Convención Americana sobre Derechos Humanos). Del mismo modo, se puede indicar que la renovación de los contratos de concesión o permiso en algunas situaciones también sea la solución más compatible con la protección máxima del usuario, y la más compatible con el régimen convencional.

En esos casos, nuevamente, hay decisiones administrativas legítimas, porque están teleológicamente justificadas y son proporcionales, de rescisión unilateral del contrato administrativo o de prórroga obligatoria en favor del contrato por interés público con fundamento en tratados de derechos humanos.

En lo que se refiere al riesgo del contrato, en la prestación del servicio público que afecte positivamente los rendimientos del concesionario, la readecuación del equilibrio económico-financiero deberá privilegiar al usuario. El equilibrio económico-financiero es intangible en caso de variaciones positivas

84 Corte Interamericana de Derechos Humanos, Caso Granier y otros (Radio Caracas Televisión) vs. Venezuela, sentencia del 22 de junio de 2015.

85 Ana Claudia Santano, "Direitos sociais e desenvolvimento: uma abordagem do ativismo judicial na Corte Interamericana de Direitos Humanos", $\mathrm{A} \& \mathrm{C}$ - Revista de Direito Administrativo \& Constitucional, n. ${ }^{\circ}$ 77, 2019. DOI: 10.21056/ aec.v19i77.1177. 
o negativas de las condiciones contractuales. Marçal Justen Filho enseña que "si los eventos extraordinarios amplían los beneficios y las ventajas del contratista, la Administración deberá revisar las condiciones y reducir sus propios encargos, para imponer la manutención de la situación original" ${ }^{\prime \prime 9}$. El impacto de los tratados de derechos humanos en ese caso debe forzosamente beneficiar al usuario de los servicios públicos delegados.

Quiere decir que, en los casos de generación de rendimientos o beneficios por encima de lo pactado y fijado en la ecuación económica-financiera, como consecuencia de eventos imprevisibles, el sobreproducto de la ecuación deberá destinarse a la mejoría del servicio y reducción pura y simple de la transferencia de la Administración. El desequilibrio positivo al contratista no significará meramente la reducción o el aumento de los encargos del Poder Público, pero obligatoriamente sí el deber de revertir en favor de algún beneficio concreto para el usuario del servicio.

Cuando se adecúe, por ejemplo, es un deber del Estado y del concesionario bajar la tarifa cuando hay ganancias no esperadas en la ecuación económicofinanciera inicia ${ }^{90}$. Cuando la tarifa ya fuere suficientemente cómoda, otros beneficios a definir en el caso concreto deberán ser revertidos a los usuarios. Como afirma Jorge Salomoni,

el beneficio no previsto del concesionario que no es redistribuido entre los usuarios, altera el derecho a la protección de los intereses económicos de este grupo. Y eso es así porque el usuario se transformó en el sujeto esencial para la conformación de la ecuación económico-financiera del contrato. El Estado y el concesionario, al ser sujetos de esa ecuación, son, por su vez, deudores del usuario ${ }^{91}$.

Al ganar importancia el usuario, incluso en licitaciones para concesión de servicios públicos, deberán ser privilegiadas aquellas propuestas que atiendan sus derechos de modo más amplio. Cualquier beneficio adicional a las condiciones mínimas de salud, seguridad, etc. de los usuarios que los oferentes incluyan en sus propuestas deberá puntuar para la adjudicación de la prestación del servicio, lo que debería ser regla obligatoria en los pliegos.

Ese debe ser uno de los criterios de atribución de la concesión o el premiso, aunque la oferta implique un precio final absoluto mayor a pagar por la

89 Marçal Justen Filho, "Ainda a questão da intangibilidade da equação econômico-financeira dos contratos administrativos", Revista do Advogado, vol. 29, n. ${ }^{\circ} 107,2009$, p. 124.

90 En el inicio del siglo XxI, el libro de Jorge Salomoni ya sugería alteraciones en el régimen de los contratos administrativos desde una perspectiva de los derechos humanos: "Como ficou demonstrado o risco para o concessionário de obras e serviços públicos se ampliou pelo afluxo da introdução constitucional dos direitos fundamentais dos usuários. Isso pode significar o início de uma necessária revisão da instituição contrato administrativo, fundamentalmente, do de concessão". JoRGE LuIS SALOMONI, Teoría general..., óp. cit., p. 392.

91 Ibíd., p. 393. 
Administración. No hay riesgo de violación al principio de economía, fiscalizado en Brasil por los Tribunales de Cuentas, pues privilegian la decisión de la autoridad administrativa en estos casos (siempre debidamente motivado) al dar cumplimiento al principio democrático que legitima la opción administrativa del sujeto electo para decidir.

Hasta que llegue el momento histórico en que el mercado pueda ofrecer todos los servicios que la sociedad reputa esenciales, como garantía de acceso universal a los ciudadanos (si es que ese momento llegará), la prestación de servicios públicos por el Estado definida como derecho humano supraconstitucional será exigible ${ }^{92}$. Es por eso que, más allá del fundamento normativo que determina que incumbe al Poder Público la prestación de servicios públicos, ellos todavía son necesarios en Brasil. Hay actividades esenciales que si la iniciativa privada no quiere o no puede prestar (por incapacidad o porque no puede prestar de forma adecuada e igualitaria), deben ser obligatoriamente emprendidas por el Estado, dada la importancia que las caracteriza para el desarrollo nacional y la concretización de los derechos fundamentales.

Se debe tener presente que la pertinencia de la manutención del instituto o la figura de los servicios púbicos en el siglo XXI no excluye la relevancia de nuevas actividades económicas ejercidas siguiendo una forma innovadora, en la lógica de la economía compartida ${ }^{93}$. Sin entrar en detalles en este punto, es importante subrayar las discusiones en torno de las plataformas de compartimiento de actividades que acaban reflejando en el modo de prestación de los servicios públicos y que no pueden ser confundidas con el servicio público en sí. No es correcto relacionar el régimen jurídico del servicio público a esas plataformas innovadoras, sin precedentes. Intentar encuadrar los hechos sin igual en la historia en categorías moldeadas para otros contextos es problemático y deslegitima el derecho ${ }^{94}$. Más que eso, la utilización de clasificaciones

92 La explicación de la relación entre "bien público" y "servicio público" que hace la Corte IDH en el Caso Ximenes Lopes vs. Brasil y en la forma como se traduce por Juan M. González Moras sirve bien para la comprensión de lo expuesto. La explicación pasa por la economía política, en la que el concepto de bienes públicos corresponde aquellos sin rivalidad en el consumo (todos consumen en la misma cantidad) y sin exclusión de los usuarios. No se puede, en cuanto a los servicios públicos, atribuir esas características de modo total, si no, los coloca como "bienes públicos impuros", porque en relación con ellos el Estado puede atribuir las características de no rivalidad y no exclusión en diferentes grados, siguiendo las decisiones políticas de cada Estado. JuAn M. GonZÁlez Moras, "El concepto de servicio público...", óp. cit., p. 423.

93 La literatura sobre economía compartida es amplia y se renueva a la velocidad de la internet, día tras día. Cfr. Lisilene Mello da Silveira, Maira Petrini y Ana Clarissa Matte ZANARDO DOS SANTOS, "Economia compartilhada e consumo colaborativo: o que estamos pesquisando?", REGE- Revista de Gestão, vol. 23, n. ${ }^{\circ} 4$, 2016, pp. 298-305.

94 Salomoni explica: "É impossivel pensar que qualduer ordenamento jurídico, sobretudo em suas normas de Direito Público, possa descontextualizar-se de uma teoria do Estado, e por sua vez, de sua plasmação constitucional e dos pressupostos fáticos que encapsula. Os juristas que, não obstante sustentem ideologias 
moldeadas para reglamentar otros escenarios, caso este de los servicios públicos, tienen en sí el potencial negativo de desestimular las innovaciones y erradicarlas, lo que solo podría interesar a monopolistas desinteresados en las mejorías que la sociedad puede usufructuar en el presente y en el futuro.

Así, es relevante identificar aquí una división entre el régimen de los servicios públicos impactado por los tratados de derechos humanos y el régimen jurídico de las actividades de economía compartida. Este último régimen, en construcción, debe partir de presupuestos diferentes al del régimen de servicio público, probablemente dejando de lado la fuerte reglamentación que aquel sufre por ser una actividad de titularidad estatal. El régimen jurídico de las actividades de economía compartida, de actividades económicas en sentido estricto, deberá ser definido por sectores ${ }^{95}$. La reglamentación, sea cual fuese, deberá tener en cuenta que los nuevos tiempos exigen que los particulares asuman actividades ligadas al interés público, lo que hace al interés privado sufrir cada vez más interferencia estatal para el resguardo de los derechos ${ }^{96}$. Eso no quiere decir que el Estado esté autorizado para sustituir la prestación de servicios públicos de elemento material semejante por aquellas actividades. Por el contrario, la prestación de servicios públicos eficientes y de calidad es un deber convencional y constitucional.

\section{CONCLUSIONES}

El régimen jurídico de las licitaciones, contratos administrativos y servicios públicos sufre impactos de los tratados internacionales de derechos humanos. Leyes nacionales que tratan esos temas pasan por una interpretación convencionalmente adecuada y deben ser, en aquello que sean incompatibles con los tratados de derechos humanos, invalidadas mediante el control de convencionalidad. La Convención de las Naciones Unidas contra la Corrupción ${ }^{97}$ prevé normas supraconstitucionales de selección de socios transparentes y eficaces, mandato en el cual está implícito un sistema simplificado de licitación que dé seguridad a los agentes contratantes, con el fin de disminuir los niveles de corrupción en el campo de las contrataciones públicas. De lege ferenda, se propone la edición de la ley de licitaciones debatida, en atención a las reglas

que compreendam todos esses planos, não os explicitam ou os ocultam, escudados na suposta apoliticidade da ciência jurídica, são coadjuvantes, na minha opinião, da deslegitimação do Direito". JORGE LuIs SALOMONI, Teoría general..., óp. cit., p. 26.

Aunque haya aspectos generales de la regulación de los servicios públicos de economía compartida, no es pertinente una regulación idéntica entre servicios de transporte (Uber, Cabify, etc.) y de hoteles (Airbnb, por exemplo).

96 Pablo Ángel Gutiérrez Colantuono, Administración pública, juridicidad y derechos bumanos, Buenos Aires: Abeledo Perrot, 2009, p. 268.

97 Incorporada al sistema brasilero y publicada por medio del Decreto n. ${ }^{\circ} 5.687 / 2006$. 
y lógica del Pacto de San José de Costa Rica y de otros tratados de derechos humanos, lo que, de conformidad con estudios empíricos, concederá simplicidad y eficiencia al proceso licitatorio en aquello que la legislación hoy vigente no es capaz de hacer. Ahora bien, el actual proyecto de la Nueva Ley de Licitaciones y Contratos Administrativos, en vía de ser aprobado por el Congreso Nacional, lamentablemente ignora los impactos de la convencionalidad, condenando a Brasil a más años de atraso en la incorporación efectiva del paradigma convencional.

Es urgente que en Brasil la teoría y la práctica de los contratos administrativos se analice a la luz de los tratados internacionales de derechos humanos. La lógica humanista de los tratados incorpora en el tema una visión contemporánea del derecho administrativo, que se aleja de un régimen jurídico autoritario en materia de contratación. En la medida en que el interés público protegido por el derecho administrativo es el interés de los ciudadanos, conforme a lo previsto en tratados de derechos humanos y de acuerdo con un conjunto de restricciones que exigen una ley en sentido formal para cualquier limitación de estos derechos, no se puede seguir admitiendo que la teoría de los contratos administrativos incorpore en la esencia de todo ajuste las llamadas "cláusulas exorbitantes". La modificación y rescisión unilateral del contrato, la aplicación de sanciones y la suspensión temporaria de pagos con inaplicabilidad de la excepción del contrato no cumplido no se justifican como prerrogativa pública disponible indistintamente a todo contrato administrativo. No es esencial, ni deseable, que el contrato administrativo esté caracterizado per se por un régimen de prerrogativas. No es tampoco esa la nota característica de la naturaleza del contrato administrativo, ajuste que, como cualquier otro, está orientado a garantizar la palabra empeñada y los compromisos asumidos entre la Administración y el particular.

Los tratados de derechos humanos incorporan el paradigma consensual en los contratos administrativos en los que el Poder Público y los agentes privados disponen de una mayor autonomía para regular las cláusulas de sus contratos, inclusive para pactar, de ser pertinente, cláusulas exorbitantes (pues es posible convencionar en las tratativas contractuales prerrogativas de la Administración). Se abandona entonces la lógica de la supremacía administrativa absoluta en todos los contratos y se refuerza el cumplimiento de las partes mediante el uso de instrumentos de garantía y coacción. El principio de igualdad y no discriminación del artículo 24 del Pacto de San José fundamenta normativamente esta conclusión, pues no toma en cuenta el establecimiento de asimetrías abstractas entre el particular y el Poder Público basadas en justificaciones concretas de su necesidad para atender el interés general ${ }^{98}$. Por esta razón, afirmar en abstracto qué conflictos contractuales deben ser resueltos en pro 
de la Administración para atender el interés de la colectividad es equivocado. Los conflictos deben ser decididos por la Administración y el Poder Judicial de acuerdo con lo pactado y para dar cumplimiento al contrato firmado y punir a quien incumple, con la aplicación de las penalidades contractuales y legales aplicables. No es raro que el sujeto pasivo de esas sanciones sea, de forma legítima, la Administración. En esa línea, cualquier limitación a la autonomía contractual de la Administración y previsión de prerrogativas debe ser establecida en ley formal específica, y siempre que sea justificada por el justo atendimiento del interés público, lo que en la mayoría de las veces lleva a un análisis del objeto contractual de cada cláusula. Es el caso, por ejemplo, de los contratos de concesión de servicio público, los cuales exigen un régimen diferenciado. De este modo, los dispositivos normativos brasileros que prevén la existencia de cláusulas exorbitantes no se aplican necesariamente en todos los contratos administrativos.

Por último, el régimen diferenciado del servicio público es necesario por cuenta de la naturaleza de esa actividad titularizada por el Estado y con fundamento convencional explícito en el artículo XXI.2 de la Declaración Universal de los Derechos Humanos, en el artículo 11.1 del Protocolo de San Salvador, entre otros tratados que mencionan el derecho. El servicio público, antes de ser un instrumento local de derecho administrativo es, en palabras de Jorge Luis Salomoni, una técnica de garantía de derechos humanos. Su fundamento supraconstitucional en declaraciones y tratados internaciones imposibilita la negativa frente a la prestación de servicios públicos por el Estado, y aunque una Constitución no los prevea, serían impositivos al menos a los países integrantes del Sistema Interamericano. El derecho humano al servicio público se sujeta al régimen de aplicación directa e inmediata, lo que torna imprescindible la existencia de la ley para exigirlo. Prestar servicios no es una discrecionalidad de los Estados, sino un deber que sujeta al Estado a responsabilidad internacional ${ }^{99}$. Más que eso, concretamente con la recepción de los tratados de derechos humanos se obliga a que en la prestación de esos servicios por el Estado o por los delegatarios, las normas de derechos humanos sean respetadas y el usuario del servicio sea previsto como la razón de ser de la actividad. El usuario, antes de ser un cliente, es un ciudadano del Estado protegido por normas convencionales. La lógica de la prestación del servicio público es orientada para privilegiar el usuario en la edición de editales de competencia, en la conducción normal del servicio y también cuando existe algún conflicto a ser decidido sobre el modo de prestación o sobre el contrato de concesión o permiso. La norma y la interpretación que atienda mejor a los intereses del usuario prevalecen sobre cualquier otra, en función de la orientación hermenéutica del principio pro persona aplicable en materia de servicios públicos. Para atender el mejor 
interés del usuario, en contratos de servicio público es permitida la rescisión unilateral del contrato administrativo o la prorrogación compulsoria en favor del contratado, orientación que debe ser seguida por el Poder Judicial cuando es llamado a dirimir estos conflictos. Igualmente, en los contratos de prestación del servicio público, el restablecimiento del equilibrio económico y financiero afectado por motivos de orden interno o externo al contrato deberá ser realizado administrativa o judicialmente de modo que privilegie y beneficie el usuario. Así, el eventual sobreproducto de la ecuación deberá orientarse a la mejoría del servicio la reducción de las tarifas, y no al aumento del beneficio del concesionario o la reducción pura y simple de la revisión de la Administración. Concretamente, esas decisiones exigirán la participación procesal de representantes de los usuarios, estudios técnicos y la satisfacción de la carga de la prueba para comprobar de qué modo los usuarios serían más beneficiados. Es inequívoco, por tanto, que la convencionalidad obliga a que se generen transformaciones importantes en la lectura del régimen jurídico de las licitaciones, contratos administrativos y servicios públicos. Todos los países integrantes del SIDH, entre ellos Brasil, se obligan a adecuar sus normas de derecho administrativo a los tratados de derechos humanos incorporados en los sistemas nacionales, so pena de declaración de inconvencionalidad en control concentrado por la Corte IDH o en control difuso por los órganos nacionales competentes.

\section{BIBLIOGRAFÍA}

\section{DOCTRINA}

Almeida, Fernando Dias Menezes de. Contrato Administrativo. São Paulo: Quartier Latin, 2012.

Bacellar Filho, Romeu Felipe. "Considerações críticas sobre as licitações e contratos administrativos". A\&C - Revista de Direitos Administrativo \& Constitucional, n. ${ }^{\circ} 14,2003$, pp. 77-85.

Bacellar Filho, Romeu Felipe. "O contrato administrativo no Brasil". Revista do Advogado, n. ${ }^{\circ} 107,2009$, pp. 155-167.

Bacellar Filho, Romeu Felipe. Direito Administrativo e o novo Código Civil. Belo Horizonte: Fórum, 2007.

Bitencourt, Caroline Müller y Janriê Rodrigues Reck. "Controle da transparência na contratação pública no Brasil - o acesso à informação como forma de viabilizar o controle social da Administração Pública". En Jaime Rodríguez-Arana Muñoz, Rogério Gesta Leal, Caroline Müller Bitencourt y Carlos Aymerich Cano (coords.), La respuesta jurídica a la corrupción en la contratación pública en Brasil y España (pp. 77-101). Navarra: Aranzadi, 2016. 
Borges, Alice Gonzales. "Considerações sobre o futuro das cláusulas exorbitantes nos contratos administrativos". Revista do Advogado, n. ${ }^{\circ}$ 107, 2009, pp. 16-24.

Carvalho Filho, José dos Santos. Manual de Direito Administrativo, 24. ${ }^{a}$ ed. Río de Janeiro: Lumen Juris, 2011.

Durán Martínez, Augusto. "Derechos de los usuarios de los servicios de interés económico general desde la perspectiva de los derechos humanos". A\&C - Revista de Direitos Administrativo \& Constitucional, n. ${ }^{\circ} 42,2010$, pp. 27-44.

Flax, Gregorio. "La sumisión del derecho administrativo a los tratados internacionales de derechos humanos". Revista de la Asociación Internacional de Derecho Administrativo, n. ${ }^{\circ} 16,2014$, pp. 353-382.

Franco, Enrique Rojas. "Los tratados internacionales como fuente de derecho". En Jaime Rodríguez-Arana Muñoz (coord.), Fuentes del derecho administrativo: tratados internacionales, contratos, como regla de derecho, jurisprudencia, doctrina y precedente administrativo. Buenos Aires: RAP, 2010.

GABARDO, EMERSON. Interesse público e subsidiariedade: o Estado e a sociedade civil para além do bem e do mal. Belo Horizonte: Fórum, 2009.

Gabardo, Emerson y Gabriel Morettini Castella. "A nova lei anticorrupção e a importância do compliance para as empresas que se relacionam com a Administração Pública". A\&C - Revista de Direito Administrativo \& Constitucional, n. ${ }^{\circ}$ 60, 2015, pp. 129-147.

Gallo Aponte, William Iván. "Una aproximación al 'riesgo de corrupción' en los contratos públicos". A\&C - Revista de Direito Administrativo \& Constitucional, n. ${ }^{\circ} 75$, 2019, pp. 39-64. DOI: 10.21056/aec.v20i75.1081.

Gomes, Luiz Flávio y Valerio de Oliveira Mazzuoli. Comentários à Convenção Americana sobre Direitos Humanos: Pacto de San José da Costa Rica, 4. ed. São Paulo: Revista dos Tribunais, 2013.

González Moras, Juan M. "El concepto de servicio público en los ordenamientos públicos globales". Revista Argentina del Régimen de la Administración Pública, n. ${ }^{\circ} 361$, 2009, pp. 395-425.

González Moras, Juan M. "El régimen del servicio público en los ordenamientos públicos globales". En Edgardo Tobías Acuña et al., Estudios de derecho público. Buenos Aires: Asociación de Docentes - Facultad de Derecho y Ciencias Sociales - UBA, 2013.

GonZÁLEZ Moras, JuAn M. "La internacionalización del derecho administrativo argentino". Revista Argentina del Régimen de la Administración Pública, n. ${ }^{\circ}$ 348, 2007, pp. 15-53. 
Grau, Eros Roberto. A ordem econômica na Constituição de 1988, 17. a ed. São Paulo: Malheiros, 2015.

Gussoli, Felipe Klein. "Dez parâmetros básicos de atuação da Administração Pública segundo os tratados internacionais de direitos humanos". Revista Digital de Direito Administrativo, vol. 6, 2019, pp. 46-70. DOI: 10.11606/issn.2319-0558.v6i2p46-70.

Gussoli, Felipe Klein. "Hierarquia supraconstitucional relativa dos tratados internacionais de direitos humanos". Revista de Investigações Constitucionais, vol. 6, n. ${ }^{\circ}$ 3, 2019.

Gussoli, Felipe Klein. Releitura do regime jurídico-administrativo e a teoria do melhor direito: impactos da convencionalidade no Sistema Interamericano de Direitos Humanos. Opinião Jurídica, Fortaleza, 2019. DOI: 10.12662/2447-6641oj.v0i0.p\%25p.0. Disponible en: https://periodicos.unichristus.edu.br/opiniaojuridica/article/view/2843.

Gutiérrez Colantuono, Pablo Ángel. Administración pública, juridicidad y derechos bumanos. Buenos Aires: Abeledo Perrot, 2009.

Gutiérrez Colantuono, Pablo Ángel. El derecho administrativo argentino y su desafío frente al régimen americano de derechos bumanos. Derecho Administrativo Iberoamericano: 100 autores en bomenaje al postgrado de Derecho Administrativo de la Universidad Católica Andrés Bello, t. I. Caracas: Ediciones Paredes, 2007.

Hernández, Jesús M. Casal. "El constitucionalismo latinoamericano y la oleada de reformas constitucionales en la región andina". Recbtsgeschichte, vol. 16, 2010, pp. 212-241.

Hungaro, Luis Alberto. "As transformações da gestão pública e o governo por contratos: a contratualização das políticas públicas". Revista Digital de Direito Administrativo, vol. 3, n. ${ }^{\circ}$ 2, 2016, pp. 367-383.

Justen FILHO, MarçAL. "Ainda a questão da intangibilidade da equação econômico-financeira dos contratos administrativos". Revista do Advogado, vol. 29, n. ${ }^{\circ}$ 107, 2009, pp. 122-131.

Justen Filho, Marçal. Curso de Direito Administrativo, 11. a ed. São Paulo: Revista dos Tribunais, 2015

Justen Filho, Marçal. Entrevista concedida a Renata Teodoro, Consultor Jurídico, 3 de ago. 2014. Disponible en línea: http://www.conjur.com.br/2014-ago-03/ entrevista-marcal-justen-especialista-direito-administrativo [consultado el 18 de diciembre de 2019].

Mazzaroppi, Fabianne y Felipe Klein Gussol. "Licitação e nova lei das estatais federais: caminhos para o desenvolvimento e sustentabilidade na Administração Pública Indireta". En Luiza de Araújo Furiatti, Maria Augusta Souza y Janaína Bettes (orgs.). O Direito entre o desenvolvimento e a sustentabilidade. Curitiba: CRV, 2017. 
Medauar, Odete. "Direito administrativo moderno". Revista dos Tribunais, 2014.

Mello, Celso Antônio Bandeira de. Curso de Direito Administrativo, 33. a ed. São Paulo: Malheiros, 2016.

Moreira Neto, Diogo de Figueiredo. "O futuro das cláusulas exorbitantes nos contratos administrativos". En Alexandre Santos de Aragão y Floriano de Azevedo Marques Neto (coords.), Direito Administrativo e seus novos paradigmas. Belo Horizonte: Fórum, 2008

RAminA, LARISSA. "A Convenção Interamericana contra a corrupção: uma breve análise". Revista Direitos Fundamentais \& Democracia, vol. 6, n. ${ }^{\circ}$ 6, 2009

RAminA, LARISSA. "Tratamento jurídico internacional da corrupção: a Convenção Interamericana contra a Corrupção da OEA e a Convenção sobre o Combate da Corrupção de Funcionários Públicos Estrangeiros em Transações Comerciais da OCDE". Revista da Faculdade de Direito UFPR, vol. 39, 2003.

SAlomoni, Jorge Luis. "Impactos de los tratados de derechos humanos sobre el derecho adminstrativo argentino". En Jorge Luis Salomoni, Romeu Felipe Bacellar Filho y Domingo J. Sesin, Ordenamientos internacionales y ordenamientos administrativos nacionales: jerarquía, impacto y derechos bumanos. Buenos Aires: Ad-hoc, 2006.

Salomoni, Jorge Luis. Teoría general de los servicios públicos. Buenos Aires: Ad-hoc, 2004.

Santano, Ana Claudia. "Direitos sociais e desenvolvimento: uma abordagem do ativismo judicial na Corte Interamericana de Direitos Humanos". A\&C - Revista de Direito Administrativo \& Constitucional, n. ${ }^{\circ} 77,2019$. DOI: $10.21056 /$ aec.v19i77.1177.

Santiago, Alfonso y Gardner Lange. "Los primeros sesenta años de la Comisión Interamericana de Derechos Humanos". A\&C - Revista de Direito Administrativo \& Constitucional, n. ${ }^{\circ} 77,2019$, pp. 11-57. DOI: 10.21056/aec.v19i77.1158.

Santofimio Gamboa, Jaime Orlando. El concepto de convencionalidad: vicisitudes para su construcción sustancial en el sistema interamericano de derechos bumanos. Ideas fuerza rectoras. Tesis posdoctoral, Universidad Carlos III de Madrid, Madrid.

Schier, Adriana da Costa Ricardo. Serviço público: garantia fundamental e cláusula de proibição de retrocesso social. Curitiba: Íthala, 2016.

Silveira, Lisilene Mello da, Maira Petrini y Ana Clarissa Matte Zanardo dos SANTOS. "Economia compartilhada e consumo colaborativo: o que estamos pesquisando?". REGE- Revista de Gestão, vol. 23, n. ${ }^{\circ} 4$, 2016, pp. 298-305.

Valle, Vivian Lima López. "Autoridade e consenso nos contratos administrativos: um reposicionamento do regime jurídico contratual brasileiro à luz da doutrina europeia dos contratos administrativos". En Luiz Alberto Blanchet, Daniel Wunder 
Hachem y Ana Claudia Santano (coords.). Eficiência e ética na Administração Pública. Curitiba: Íthala, 2015.

Valle, Vivian Lima LóPEZ. Contratos administrativos e um novo regime jurídico de prerrogativas contratuais na Administração Pública contemporânea. Belo Horizonte: Fórum, 2018.

Zárate Pérez, Aníbal. "La especialidad relativa de la potestad sancionadora en materia de servicios públicos domiciliarios". En Ángela María Amaya Arias, Alberto Montaña Plata y Jorge Iván Rincón Córdoba (eds.), El poder sancionador de la administración pública: discusión, expansión y construcción. Bogotá: Universidad Externado de Colombia, 2018.

Zárate, Aníbal y Camilo Perdomo Villamil. "El deber de información como presupuesto procedimental para el ejercicio de la potestad reglamentaria en Colombia". A\&C - Revista de Direito Administrativo \& Constitucional, n. ${ }^{\circ}$ 76, 2019, pp. 41-82. DOI: 10.21056/aec.v19i76.1076

\section{Jurisprudencia de la Corte Interamericana de Derechos Humanos}

Corte Interamericana de Derechos Humanos. Opinión Consultiva n. ${ }^{\circ}$ 18/2003. Condición Jurídica y Derecho de los migrantes sin documentos. Publicada el 17 de septiembre de 2003.

Corte Interamericana de Derechos Humanos. Caso Ximenes Lopes vs. Brasil. Sentencia del 4 de julio de 2006

Corte Interamericana de Derechos Humanos. Caso Granier y otros (Radio Caracas Televisión) vs. Venezuela. Sentencia del 22 de junio de 2015.

Corte Interamericana de Derechos Humanos. Titularidad de derechos de las personas jurídicas en el Sistema Interamericano de Derechos Humanos (interpretación y alcance del artículo 1.2, en relación con los artículos 1.11, 8, 11.2, 13, 16, 21, 24, 25, 29, 30, 44, 46, e 62.3 de la Convención Americana sobre Derechos Humanos, así como el artículo 8.1 A e B del Protocolo de San Salvador). Opinión Consultiva n. ${ }^{\circ} 22 / 16$. Publicada el 26 de febrero de 2016. 